\title{
TESTS OF INTEGRAL AND SURFACE WATERPROOFINGS FOR CONCRETE
}

\author{
By C. H. Jumper
}

\section{ABSTRACT}

The paper is a report of the study of integral and surface waterproofing materials for concrete.

Fifty commercial integral waterproofing materials were incorporated into a 1:3:6 concrete and subjected to a water pressure of $20 \mathrm{lbs} . /$ in. $^{2}$ for one year and their permeability noted in comparison with plain concrete of the same quality tested in a similar manner. Strength and absorption results were also obtained. The materials are grouped in accordance with their chemical composition and a detailed discussion is given of the effect of each material on concrete as well as a general summary of the effects of each group.

The 50 surface waterproofing materials were applied to 3 by 6 inch concrete cylinders and their absorption determined, after immersion in water, at regular intervals up to one year. A comparison of these results with the absorption figures obtained on uncoated concrete, given the same treatment, are presented and discussed. A general résumé is given of the results obtained in the study of integral and surface waterproofings.

\section{CONTENTS}

1. Introduction

II. Method of fabrication of integral test specimens..... 1148

1. Permeability specimens.......................... 1148

2. Strength and absorption specimen..... 1149

III. Method of test (integral)

1. Permeability tests...... 1150

2. Absorption tests

3. Compresision tests

IV. Integral waterproofing materials

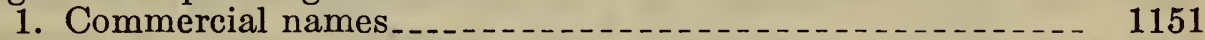

2. Composition and method of incorporation

V. Discussion of results

1. Plain concrete

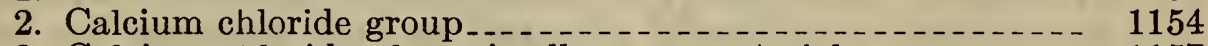

3. Calcium chloride plus miscellaneous materials group $\ldots$

4. Group containing soap .

5. Group containing hydrated lime and soap.

6. Gioup containing finely ground subdivided materials....

7. Group containing miscellaneous materials

VI. Summary of results (integral waterproofings)

VII. Method of fabrication and test of surface waterproofings.

VIII. Surface waterproofing materials_._.

1. Commercial names.

2. Composition and method of application $\ldots$

IX. Discussion of results of absorption test up to one year.

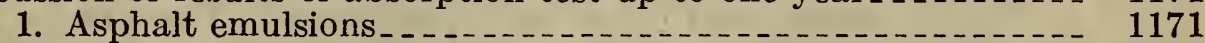

2. Bituminous solutions

3. Finely ground iron

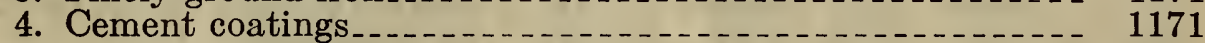

5. Transparent coatings... 1172

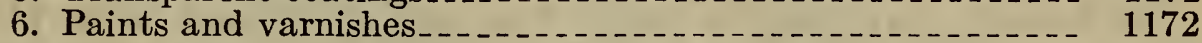

X. Discussion of results of absorption tests subsequent to one year.-- 1172

XI. Summary (surface) _._.

XII. Résumé and conclusions.

XIII. Acknowledgments_....... 1177 


\section{INTRODUCTION}

The introduction and sale of a large number of newly named integral and surface waterproofing materials for concrete has resulted in frequent requests to the bureau by the several departments of the Government and by the public for information regarding the relative merits of these compounds. The bureau has, therefore, felt the necessity of supplementing the work published in Technologic Paper No. 3 of the bureau in 1911, inasmuch as it is possible that since the issuing of that publication some of the products on the market may be new compounds not included in the former work or that some of the older ones may have been improved.

In this investigation, it was first necessary to develop a concrete that when subjected to a water pressure of $20 \mathrm{lbs}$./in. ${ }^{2}$ would be permeable to a slight extent, and could be duplicated so as to give reasonably consistent results. Laboratory-made specimens of what would generally be called poor concrete invariably showed no or erratic permeability. Several hundred specimens were made using mixes of concretes varying from $1: 1: 5$ to $1: 4: 6$. The water-cement ratio and the grading of sand and gravel were varied for each of the mixes. The tests on these several mixes showed that a mix of dry consistency was too permeable and a mix that was wet enough to be workable was practically impervious. 'The medium flow between a dry mix and a workable mix, that would allow a small amount of water to pass through the specimen, could not be obtained on mixes that are commonly used. For example, in trying to design a $1: 2: 4$ mix that would be permeable to a slight extent, the grading of sand and gravel were kept constant and the water-cement ratio was varied from 0.72 to 0.75 and 0.79 . The specimens with a water-cement ratio of 0.72 were quite permeable and the results quite inconsistent, but the specimens with a water-cement ratio of 0.75 and 0.79 were impermeable. It seemed practically impossible to make a $1: 2: 4 \mathrm{mix}$ that was just dry enough or just wet enough to give a concrete that was just slightly permeable and, therefore, might be rendered less pervious through the addition of the waterproofing and that could be duplicated. As a result of considerable experimentation, a $1: 3: 6$ mix by volume was finally adopted as best meeting the laboratory requirements.

\section{METHOD OF FABRICATION OF INTEGRAL TEST SPECIMENS}

\section{PERMEABILITY SPECIMENS}

Portland cement, complying with the standards of the United States Government, Potomac River sand and a gravel graded between No. 4 to $3 / 8$ inch, were used in all test specimens. The grading analysis of the Potomac River sand gave the following percentages retained on the sieves: No. 4 sieve 3 , No. 8 sieve 18 , No. 16 sieve 32, No. 30 sieve 60, No. 50 sieve 97 , and No. 100 sieve 99.

Sufficient materials to make five test specimens were placed in a large galvanized-iron pan and thoroughly dry mixed. Water was then added to give a water-cement ratio of 1.26 by volume. The mixing was continued for two minutes by hand. The concrete was then placed in five metal cyclinders 5 inches in diameter and 5 inches 
high by pouring through a cone containing baflles. This served to break up the mix and give an even distribution over the area of the mold. The mix was placed in three layers, each layer was stirred just sufficiently with an iron stirring rod to assist in distributing the concrete evenly over the mold. No tamping was done. After the concrete was placed in the molds, an outside cylinder of galvanized iron, 7 inches in diameter and 2 inches high, was placed around each mold and the 1-inch space was filled with a fairly wet 1:2 mix of cement and sand.

The inside 5 -inch mold was then carefully withdrawn so as not to disturb the concrete mix. The outside mold was allowed to remain permanently around the concrete. The five spec mens were then securely held to the top of a flow table to prevent sliding and given 30 one-eighth inch drops. This caused the concrete to be compacted and produced a bond between the concrete and the outside layer of mortar. The surplus concrete was then struck off with a trowel and the specimens were removed to a laboratory table and covered with steel plates. After 24 hours the plates were removed and the concrete surfaces were wire-brushed to remove all neat cement that might have come to the top or settled to the bottom.

A neat cement cap approximately one-eighth inch thick was spread over the 1-inch mortar surface surrounding the 5-inch diameter specimen. The test pieces were then placed in the damp closet for 24 hours after which the neat cement caps were scraped to a smooth surface. The specimens were then allowed to remain in the damp closet until seven days old. All operations were conducted in a constant temperature room maintained at $70^{\circ} \mathrm{F} . \pm 3^{\circ}$.

The integral waterproofing materials were supplied either as a powder, paste, or liquid. The powders were added directly to the dry mix and thoroughly incorporated in the mix before the water was added. The paste and liquid waterproofing compounds were added to the mixing water. In all cases the directions for mixing and the amount to be used per bag of cement as furnished by the manufacturer were carefully complied with.

In addition to making the 50 batches, each containing one of the 50 integral waterproofing compounds, 6 batches were made in the same manner without the addition of compounds and were used as a basis for comparison for determining the efficiency of the waterproofing compounds.

\section{STRENGTH AND ABSORPTION SPECIMENS}

Portland cement as used in the permeability specimens. Potomac River sand and No. 4 to $3 / 8$-inch gravel were used. Sufficient materials to make twelve 3 by 6 inch cylinders, of a 1:3:6 mix by volume were placed in a large galvanized iron pan and thoroughly mixed by hand. Water was then added to give a concrete with a watercement ratio of 1.26 by volume. After mixing for two minutes, the concrete was placed in the 3 by 6 inch cylinder molds in three layers, each layer being rodded 25 times. Nine cylinders from each batch were capped with neat cement and three to be used for the absorption tests struck off flush with the top of the mold.

The waterproofing agents were added to the concrete mixes in the amounts and manner suggested by each manufacturer. On several occasions concrete was made to which no waterproofing was added; the specimens so made served as "blanks." 


\section{METHOD OF TEST (INTEGRAL)}

\section{PERMEABILITY TESTS}

After the curing period of seven days in the damp closet, the specimens to be tested for permeability were placed in the test piece holders. A holder consists of two cast-iron pipe flanges. The upper flange is closed with a pipe plug through which passes a $1 / 2$-inch pipe supplied with a union for attaching to the water line. The plug is also supplied with a 14 -inch petcock for venting the air at the time of starting the test. The lower flange is also closed with a pipe plug through which passes a $1 / 2$-inch pipe to which a rubber hose is connected to deliver the water passing through the specimen to a measuring cylinder. Rubber gaskets are used between the test piece and the flanges. Eight bolts are used to draw the flanges together, thus making a tight seal so that no water can leak out between the flanges. The test piece after being securely fastened in the holder was placed on a rack and connected to the water line.

Water was supplied from the city main and was passed through a sand filter to remove all sediment. A control valve was placed in the line between the test specimens and the filter and a pressure of 20 pounds was maintained in the system at all times. The set up consisted of six racks that accommodated 36 specimens each.

The first determinations of the flow were taken 24 hours after the test specimens were placed under pressure and then daily until the twenty-eighth day. At the age of 28 days, three test specimens were selected from the five under test for each compound, which appeared to have uniform permeability and were representative of the compound. Observations were then taken each week, covering a period of one year, on the three test specimens.

At the end of the year period the test specimens were taken down and thoroughly wire-brushed to remove any rust or sediment that might have collected on the top of the specimen during the year exposure. They were again placed in the holders and the test continued for two months. Observations were made at regular intervals after the first 24 hours.

After this 2-month test the specimens were again taken down, removed from the holder, and allowed to dry in the air of the laboratory for one month. They were then placed under pressure and the permeability noted over a period of a month.

The average values, taken at regular intervals, of the amount of water passing through the three specimens of any one mix are reported in cubic centimeters per 100 square centimeters of surface per hour. These results are presented in the accompanying figures.

\section{ABSORPTION TESTS}

The absorption cylinders were cured in the damp closet for 19 days. They were then placed in an oven at $65^{\circ}$ C., through which dry air was circulated to promote drying, and dried to constant weight.

At 28 days they were weighed, then immersed in water for one hour, then dried with a damp towel, weighed, and immersed again. This procedure was followed and the absorption determined at 1 hour, 2 hours, 4 hours, 24 hours, 48 hours, and 72 hours. They were then placed in the damp closet for one year. At the end of this period they were again dried to constant weight at $65^{\circ} \mathrm{C}$. and the above procedure repeated. 
The absorption was computed from the recorded weights, and is reported in per cent of the dry weight.

\section{COMPRESSION TESTS}

Three of the 3 by 6 inch cylinders from each of the 50 mixes containing waterproofing materials and three cylinders from several mixes containing no waterproofing or additive materials were tested in compression, after curing in the damp closet, at the age of 7 days, 28 days, and 1 year.

The compressive strength in pounds per square inch given in the table is the average of the three cylinders from each mix at each age.

\section{INTEGRAL WATERPROOFING MATERIALS}

\section{COMMERCIAL NAMES}

The materials used in this investigation were furnished by the manufacturer under the following trade names:

A. B. Integral Hardner.

A. B. Waterproofing Powder. Acqua-Pruf.

Adensite.

Alberoyd.

Alkalgel A.

Alkalgel B2.

Alkalgel B3.

Anti-Hydro.

Aquabar Aquatite Liquid.

B. C. C. Oil Waterproofing.

Biber A.

Butyl Stearate.

Cal.

Celite.

Ceresit Liquid.

Ceresit Paste.

Ceresit Powder.

Colloy.

Con wat co Mix.

Dragon Super Cement.

Fluresit.

G. F. 10.

G. F. 12 Accelerator.

\author{
Hydratite Liquid. \\ Hydratite No. 4 Paste. \\ Hydrocide Paste. \\ Hydrocide Powder. \\ Konset. \\ Luigi Serra. \\ Master Builders Concentrated Liquid. \\ Master Builders New Master Mix. \\ Master Builders Paste. \\ Medusa Waterproofed Cement. \\ Medusa Waterproofing Powder. \\ Non-Poro. \\ Penetrite Paste. \\ Penetrite Powder. \\ Permantite. \\ Rubberoid Waterproofing Paste. \\ Se-Ment-Seal. \\ Sika No. 1. \\ Sulco Liquid. \\ Toxement Paste. \\ Toxement Powder. \\ Toxmix Clear. \\ Tricosal Normal.
}

In addition to these compounds a high calcium lime, a dolomitic lime, and potter's flint were included in the investigation.

\section{COMPOSITION AND METHOD OF INCORPORATION}

The waterproofings have been grouped in accordance with their chemical composition. The first group of waterproofings are those containing calcium chloride and water, the second contains calcium chloride with miscellaneous materials, the third soaps, the fourth hydrated lime with soaps, the fifth finely subdivided materials, and the sixth group miscellaneous materials. These waterproofing materials are briefly described in Table 1 . 
TABLE 1.-Composition and method of incorporation of integral waterproofing materials

Group No. 1. CALCIUM CHLORIDE

\begin{tabular}{|c|c|c|}
\hline $\begin{array}{l}\text { Mate- } \\
\text { rial } \\
\text { No. }\end{array}$ & Composition & Method of incorporation \\
\hline 24 & $\begin{array}{l}\text { Light yellow colored liquid with a small amount of flocculent } \\
\text { precipitate. Contains about } 73 \text { per cent water; the remainder } \\
\text { is calcium chloride and less than } 1 \text { per cent of a saponifiable } \\
\text { resinous material. }\end{array}$ & $\begin{array}{l}\text { Use } 1 \text { gallon in the gaging water } \\
\text { for one barrel of cement. }\end{array}$ \\
\hline 26 & $\begin{array}{l}\text { Turbid liquid. Contains about } 60 \text { per cent water; the remain- } \\
\text { der is calcium chloride. } \\
\text { Clear solution. Contains about } 73 \text { per cent water; the remain- } \\
\text { der is calcium chloride. }\end{array}$ & $\begin{array}{l}\text { Use } 1 \text { quart in the gaging water } \\
\text { per bag of cement. } \\
\text { Do. }\end{array}$ \\
\hline 27 & $\begin{array}{l}\text { Clear solution. Contains about } 65 \text { per cent water; the remain- } \\
\text { der is calcium chloride. }\end{array}$ & $\begin{array}{l}\text { Add } 1 \text { gallon to each } 12 \text { gallons } \\
\text { of water and use as gaging } \\
\text { water. }\end{array}$ \\
\hline 28 & $\begin{array}{l}\text { Light yellow colored turbid solution. Contains about } 70 \text { per } \\
\text { cent water; the remainder is essentially calcium chloride. }\end{array}$ & $\begin{array}{l}\text { Use } 1 \text { gallon in the gaging water } \\
\text { per barrel of cement. }\end{array}$ \\
\hline 30 & $\begin{array}{l}\text { Turbid solution. Contains about } 60 \text { per cent water; the re- } \\
\text { mainder is calcium chloride and a small amount of calcium } \\
\text { bydroxide. }\end{array}$ & $\begin{array}{l}\text { Use } 1 \text { gallon to each } 10 \text { gallons } \\
\text { of water and use as gaging } \\
\text { water. }\end{array}$ \\
\hline 33 & Dark purple colored liquid. Contains about 60 per cent water & $\begin{array}{l}\text { Use } 1 \text { quart in the gaging water } \\
\text { per bag of cement. }\end{array}$ \\
\hline 35 & $\begin{array}{l}\text { Turbid solution. Contains about } 73 \text { per cent water; the re- } \\
\text { mainder is calcium chloride. }\end{array}$ & \\
\hline 7 & Calcium oxychloride & $\begin{array}{l}\text { Use } 5 \text { pounds to a bag of cement } \\
\text { and mix with the cement } \\
\text { before adding water. }\end{array}$ \\
\hline
\end{tabular}

Group No. 2. CALCIUM CHLORIDE PLUS MISCELLANEOUS MATERIALS

Thick white semiliquid. Contains about 75 per cent water; the remainder is calcium chloride, silica, and calcium stearate. About 13 per cent of fatty acids are present as stearate.

White paste. Contains about 73 per cent water; the remainder is calcium chloride and calcium stearate. About 4 per cent of fatty acids are present as stearate.

Gray turbid liquid. Contains about 57 per cent water; the remainder is calcium chloride, aluminum chloride, and silica.

37 Thick white liquid. Contains about 65 per cent water; the remainder is calcium chloride and ammonium stearate. About 11 per cent of fatty acids are present as stearate.

38 Black colored, odorless liquid. Contains about 66 per cent water; the remainder is calcium chloride, aluminum chloride, silica, and a black dy $\theta$.

39 Yellow colored paste. Contains about 84 per cent water; remainder is calcium chloride and colloidal silica.
Mix 1 gallon of material to 1 gallon of water. Use 2 quarts of the mixture as gaging water per bag of cement.

Use two-thirds quart in gaging water per bag of cement.

Use 1 quart in gaging water for 100 pounds of cement.

Use 1 gallon to each 33 gallons of gaging water.

Use 1 quart to one bag of cement; add to the mix after the water has been added.

Use 1 part of paste to 10 parts of water as gaging water.

Group No. 3. SOAPS

13 Thick white paste. Contains about 89 per cent of water; the remainder is ammonium stearate. About 11 per cent of fatty acids are present as stearate.

14 Thick white paste. Contains about 87 per cent of water; the remainder is ammonium stearate. About 13 per cent of fatty acids are present as stearate.

18 Thick white semiliquid completely soluble in water. Contains sodium stearate. A bout 9 per cent of fatty acids are present as stearate.

22 Thick white paste. Contains water and ammonium stearate. A bout 23 per cent of fatty acids are present as stearate.

23 Thick white paste. Contains water and ammonium stearate. A bout 19 per cent of fatty acids are present as stearate.

29 Yellow turbid liquid. Contains water, ammonium oleate, and a very small amount of calcium chloride. A bout 5 per cent of fatty acids are present as oleate.

36 Thick cream colored liquid. Contains about 85 per cent water; remainder is ammonium oleate and a small amount of unsaponifiable oil.
Use 1 gallon to 34 gallons of water and use as gaging water.

Use 1 gallon to 32 gallons of water and use as gaging water.

Use 6 pounds in gaging water per barrel of cement.

Use 2 pounds in gaging water per bag of cement.

Do.

Use 1 quart in gaging water per bag of cement.

Use 1 gallon to each 36 gallons of water as gaging water. 
TABLE 1.-Composition and method of incorporation of integral waterproofing materials-Continued

Group No. 4. HYDRATED LIME PLUS SOAP

\begin{tabular}{|c|c|c|}
\hline $\begin{array}{l}\text { Mate- } \\
\text { rial } \\
\text { No. }\end{array}$ & Composition & Method of incorporation \\
\hline 1 & $\begin{array}{l}\text { White powder. Contains dolomitic hydrated lime and calcium } \\
\text { stearate. About } 5 \text { per cent of fatty acids are present as ste- } \\
\text { arate. }\end{array}$ & $\begin{array}{l}\text { Use } 2 \text { pounds to one bag of } \\
\text { cement. Mix dry with ce- } \\
\text { ment. }\end{array}$ \\
\hline 2 & $\begin{array}{l}\text { White powder. Contains dolomitic hydrated lime and calcium } \\
\text { stearate. About } 10 \text { per cent of fatty acids are present as } \\
\text { stearate. }\end{array}$ & $\begin{array}{l}\text { Use } 2 \text { per cent by weight of } \\
\text { cement and mix with the } \\
\text { cement before adding water. }\end{array}$ \\
\hline 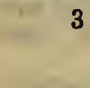 & $\begin{array}{l}\text { White powder. Contains an impure dolomitic hydrated lime } \\
\text { and calcium stearate. About } 9 \text { per cent of fatty acids are } \\
\text { present as stearate. }\end{array}$ & $\begin{array}{l}\text { Use } 2 \text { pounds per bag of cement } \\
\text { and mix dry with the ce- } \\
\text { ment. }\end{array}$ \\
\hline 5 & $\begin{array}{l}\text { White powder. Contains hydrated lime, alum, and calcium } \\
\text { stearate. About } 9 \text { per cent of fatty acids are present as ste- } \\
\text { arate. }\end{array}$ & Do. \\
\hline$\frac{4}{7}$ & $\begin{array}{l}\text { White powder. Contains hydrated lime and calcium stearate. } \\
\text { About } 2 \text { per cent of fatty acids are present as stearate. }\end{array}$ & Do. \\
\hline 8 & $\begin{array}{l}\text { Pink powder. Contains hydrated lime, calcium oleate, and } \\
\text { small amount of iron oxide. About } 12 \text { per cent of fatty acids } \\
\text { are present as oleate. }\end{array}$ & $\begin{array}{l}\text { Use } 2 \text { per cent of weight of } \\
\text { cement and mix dry with the } \\
\text { cement. }\end{array}$ \\
\hline
\end{tabular}

\section{Group No. 5. FINELY SUBDIVIDED MATERIALS USED AS FILLERS}

Diatomaceous silica

High calcium hydrated lime

Hydrated dolomitic lime.

Finely ground silica and bentonite

Finely ground potter's flint

Light gray powder; finely ground soapstone
Use 3 pounds per bag of cement and mix with cement before adding water.

Use 10 per cent of the weight of cement and mis with cement before adding water. Do.

Use 5 per cent of the weight of cement and mix with cement before adding water.

Use 10 per cent of the weight of cement and mix with cement before adding water. Do.

\section{Group No. 6. MISCELLANEOUS MATERIALS}

White powder. Contains barium sulphate, calcium and magnesium silicate, and about 7 per cent of uncombined low melting fatty acids.

Gray powder. Contains finely ground silica and from 1 to 2 per cent of naphthalene.

Thick white paste. Contains about 85 per cent water; the remainder is colloidal silica and a fluosilicate.

Thick yellow paste. Contains about 40 per cent of water, about 30 per cent of petroleum jelly, and about 30 per cent of lime.

Thick gray colored paste. Contains cellulose material and wax held in an ammonical copper solution.

Thick gray colored paste. Composition is only slightly different than No. 15.

Thick dark green paste. Similar to No. 15 and No. 16, but does not contain as much wax and cellulose as the other two.

Thick white paste. Contains about 37 per cent water; the remainder is barium sulphate, silica, calcium, and about 6 per cent of uncombined low melting fatty acid.

Thick brown colored liquid with an aromatic odor. Contains about 85 per cent water; the remainder is silica, hydrated lime, and alum.

Thick black liquid. Contains coal tar cut with benzene.
Use 2 pounds to 100 pounds of cement and mix with the cement before adding water. Use 6 pounds to 135 pounds and 14 ounces of cement and mix with the cement before adding water.

Use 214 pounds to one bag of cement and thoroughly mix with the gaging water.

Use 1 pound for each bag of cement and add to the gaging water.

Use in the proportion of 1 part to 20 parts of gaging water. Do.

Use in the proportion of 1 part to 28 parts of gaging water.

Use 2 pounds per bag of cement and add to the gaging water.

Use 1 gallon to one barrel of cement and add to the gaging water.

Use 1 pound to each 100 pounds of cement. Add to the mix after the water has been added. 
TABLE 1.-Composition and method of incorporation of integral waterproofing materials-Continued

Group No. 6. MISCELLANEOUS MATERIALS-Continued

\begin{tabular}{|c|c|c|}
\hline $\begin{array}{l}\text { Mate- } \\
\text { rial } \\
\text { No. }\end{array}$ & Composition & Method of incorporation \\
\hline 41 & $\begin{array}{l}\text { Portiand cement containing a water repellent material, such as } \\
\text { calcium stearate. }\end{array}$ & $\begin{array}{l}\text { Use in the place of and in the } \\
\text { same proportion as the } \\
\text { standard cement. }\end{array}$ \\
\hline 42 & $\begin{array}{l}\text { Portland cement containing a specially prepared form of cal- } \\
\text { cium sulphate. }\end{array}$ & Do. \\
\hline 43 & Butyl stearate & $\begin{array}{l}\text { Use } 1 \text { pound to each } 100 \text { pounds } \\
\text { of cement. Add to the mix } \\
\text { after the water has been } \\
\text { added. }\end{array}$ \\
\hline 44 & $\begin{array}{l}\text { Heavy oil. Contains mineral oil and about } 12 \text { per cent of stearic } \\
\text { acid. }\end{array}$ & $\begin{array}{l}\text { Use } 2 \text { quarts tol } 1 \text { bag of cement. } \\
\text { Add to the mix after the } \\
\text { water has been added. }\end{array}$ \\
\hline 45 & $\begin{array}{l}\text { Thick brown-colored liquid. Contains sodium silicate and an } \\
\text { organic nitrogenous material resembling glue. }\end{array}$ & $\begin{array}{l}\text { Use } 1.2 \mathrm{~kg} \text { of solution to } 100 \mathrm{~kg} \\
\text { of cement and add to the } \\
\text { mixing water. }\end{array}$ \\
\hline
\end{tabular}

\section{DISCUSSION OF RESULTS}

\section{PLAIN CONCRETE}

The average results obtained in six different batches of concrete of three specimens each are presented in Figure 1. These batches were made of $1: 3: 6$ concrete, free from waterproofing admixtures. The deviation of the results of each batch from the average of the entire group, represented by the dash line, indicates the probable error in the results reported for mixes containing waterproofing materials. The average of this group of specimens is used as a basis for comparing the relative efficiencies of the compounds tested.

The plain concrete specimens were not noticeably affected by wire brushing. The very slight increase in permeability after this treatment is negligible.

The permeability of all the specimens was increased by drying. The initial permeability was high but decreased appreciably in one month's time.

The results graphically presented in Figure 2 show the deviations from the average which occurred after one year, after wire brushing and after one month's drying of the specimens in the air of the laboratory.

The results obtained with the individual specimens of plain concrete and also with the concrete containing waterproofing compounds were quite consistent except after the specimens were dried for one month in the air of the laboratory. These results, in some cases, were quite erratic.

\section{CALCIUM CHLORIDE GROUP (FIGS. 2 AND 3)}

Permeability.-Nos. $24,25,26,27,28,30,33$, and 35 are essentially calcium chloride in a water solution, containing from 30 to 40 per cent of the solute. They were added to the concrete mix in the proportion of 1 quart of the solution to one bag of cement except Nos. 27 and 30. About 3 quarts of No. 27 and about 4 quarts of No. 30 were added per bag of cement. No. 7 is a calcium oxy- 
chloride powder. Five pounds of this sample were added per bag of cement to the dry mix.

The mixes containing Nos. 27 and 30 were markedly less permeable than the standard for the earlier periods. In these two the calcium chloride was present in greater quantities than in the others, as indicated above. No. 7 , the calcium oxychloride, also gave a less permeable mix.

At the 28-day period Nos. 7 and 30 gave the same results as the standard, while the other samples showed a greater permeability. At

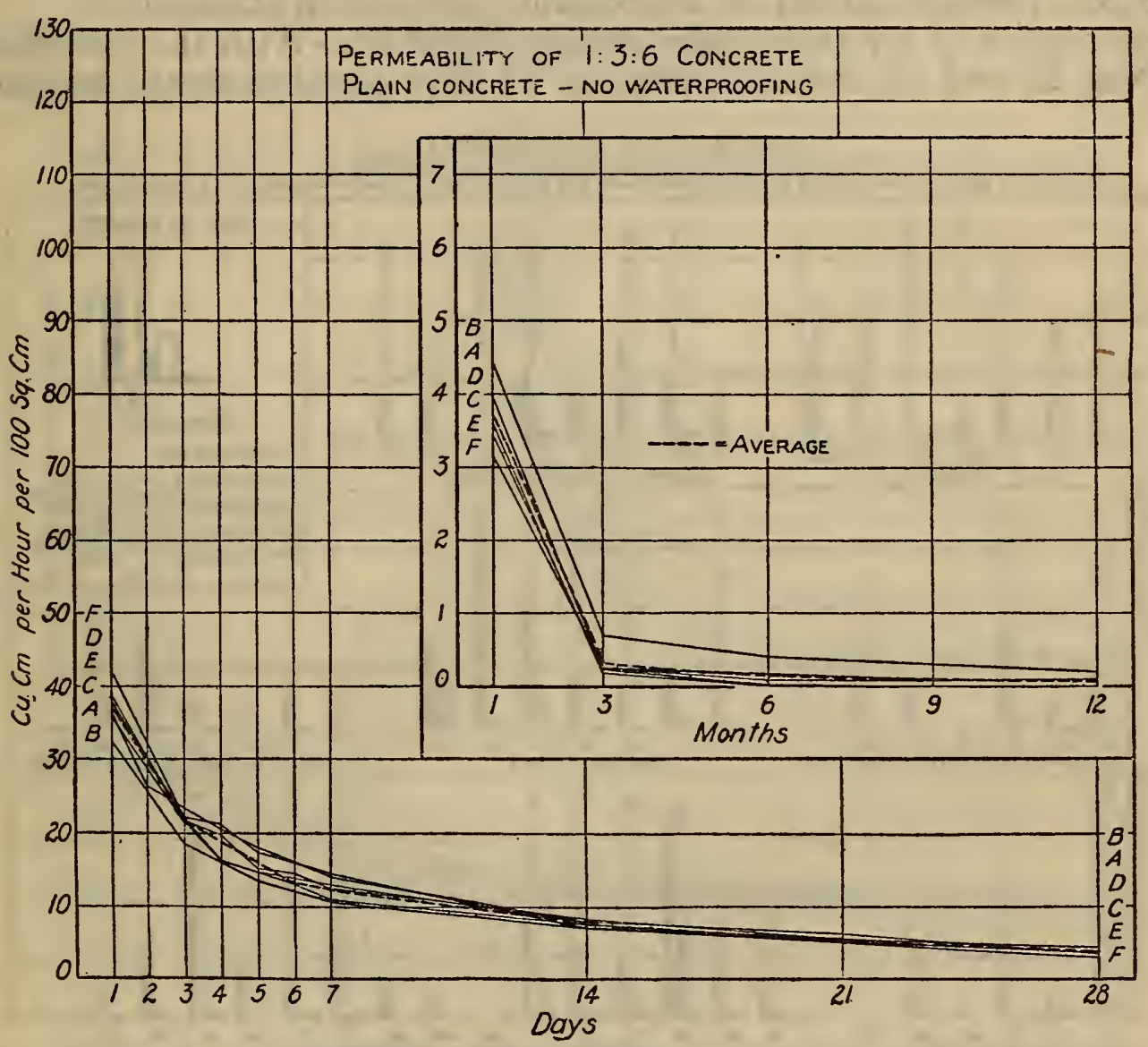

FiguRe 1.-Permeability of $1: s: 6$ concrete containing no waterproofing

the end of one year Nos. 7 and 24 were impermeable. Nos. 25 and 28 were more permeable than the standard. The other samples of this group were about the same as the standard.

Wire brushing had no appreciable effect on the permeability of any of the specimens of this group.

One month's drying in the laboratory caused an appreciable increase in the initial permeability of Nos. 25 and 26 . The amount of water passing through these specimens decreased considerably, but they remained more permeable than the standard at the end of one month. No. 28 showed a slight increase in permeability, after drying, both initially and at the end of the test. Nos. 24, 27, 30, 33, and 35 did not vary appreciably from the standard. No. 7 did not show an increase in permeability after drying and was the least permeable in this group. 
Compressive strength (Table 2).-The addition of this group of samples to the concrete caused an increase in strength in all the specimens at seven days, compared to the untreated concrete.

The 28-day strength was higher than the standard in specimens containing Nos. $24,25,26,30$, and 35 , while Nos. 27,28 , and 33 did not show a noticeable deviation from the standard. No. 7 showed a slight decrease in strength. As compared to the standard the 1year strength was higher for the treated concrete, with the exception of Nos. 28 and 33 which remained about the same as the standard, and No. 7 which caused an appreciable decrease in strength.

Absorption of specimens after curing (Table 2).-With the exception of Nos. 27 and 33, the absorption of 19 days cured concrete contain-

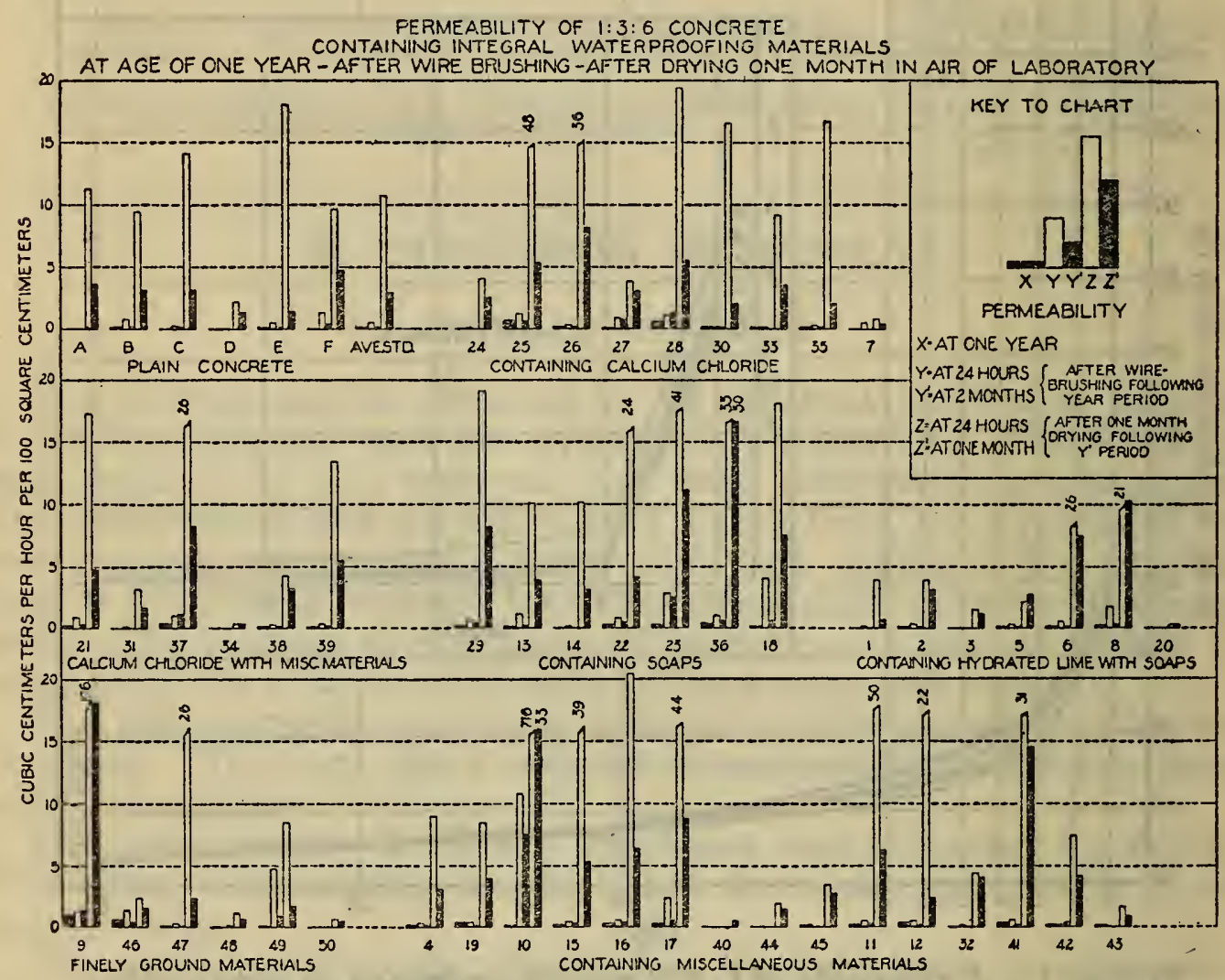

FIGURE 2.-Permeability of $1: 3: 6$ concrete containing integral waterproofing materials at the age of one year, after wire brushing and after drying one month in the air of the laboratory

ing this group of waterproofings was lower than that of untreated concrete, for 1,2 , and 4 hours immersion in water. The absorption for 24 and 48 hours immersion was about the same for both treated and untreated concrete.

After curing for one year the specimens containing this group did not vary appreciably from the untreated concrete when subjected to 1,2 , and 4 hours' immersion in water. The concrete containing No. 24 was the only exception, showing a higher absorption than the standard for all periods of immersion. The absorption of the treated specimens for the 24 and 48 hour periods was less than for the untreated concrete, except for Nos. 24 and 33. 
3. GROUP CONTAINING CALCIUM CHLORIDE PLUS MISCELLANEOUS MATERIALS (FIGS. 2 AND 4)

Permeability.-Waterproofings Nos. 21, 31, 34, 37, 38, and 39 contain calcium chloride with the addition of other materials, such as soap, silica, and aluminum chloride. The quantity of each compound incorporated into the mix per bag of cement was 1 quart of No. $21,2 / 3$ quart of No. 31, nearly 1 quart of No. 34, 1.1 quarts of No. 37,1 quart of No. 38 , and about 4 quarts of No. 39 .

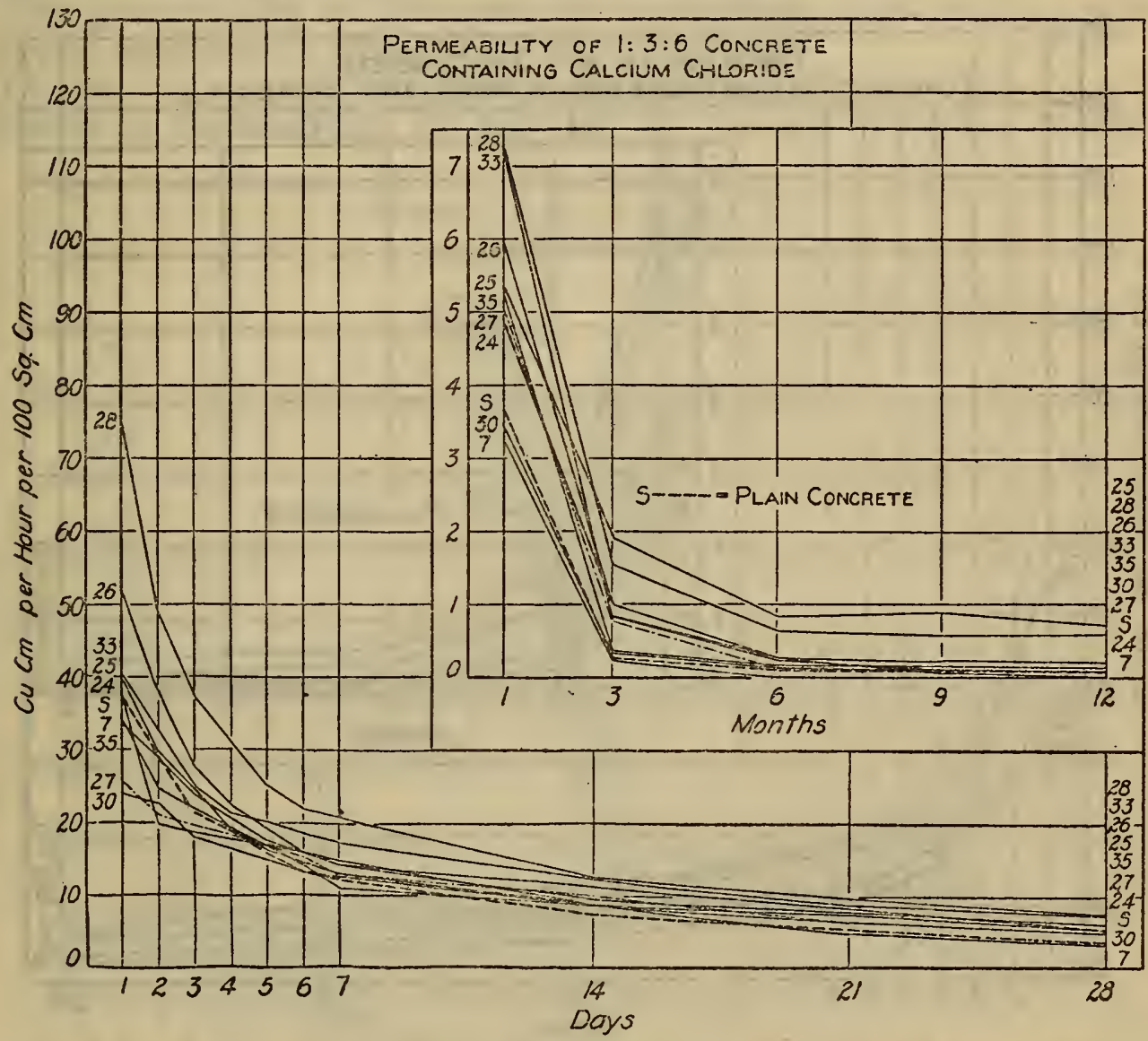

Figure 3.-Permeability of $1: 3: 6$ concrete containing calcium chloride

The initial permeability of concrete containing Nos. 21, 37, and 39 was greater than that of the untreated concrete. At 14 days the permeability of No. 39 decreased and became the same as that of the standard at 28 days, remaining in this relative position for the other periods, while Nos. 21 and 37 remained appreciably more permeable throughout the test.

Nos. 31,34 , and 38 caused a negligible difference in permeability initially and at seven days as compared to the untreated concrete. From the 7-day period to the end of the test Nos. 31 and 34 caused a decrease in permeability, while No. 38 showed an increase, but. approached the standard at nine months.

The permeability of this group was not altered appreciably by wire brushing.

A month's drying of these specimens in the air of the laboratory increased the permeability of tho concrete containing $\mathrm{No} .37$, while Nos. 21 and 39 yielded nearly the same results as the standard. 
Concrete containing No. 34 was the least affected by the drying treatment being less permeable than the standard. Nos. 31 and 38 also caused a decrease in permeability.

Compressive strength (Table 2).- With the exception of No. 31, the addition of the waterproofings only slightly affected the strength at any age.

Absorption after curing (Table 2).-This group caused a decrease in absorption for the 1,2, and 4 hour periods, Nos. 21 and 37 causing a marked decrease. Nos. 21 and 37 were less absorptive at 24 and 48

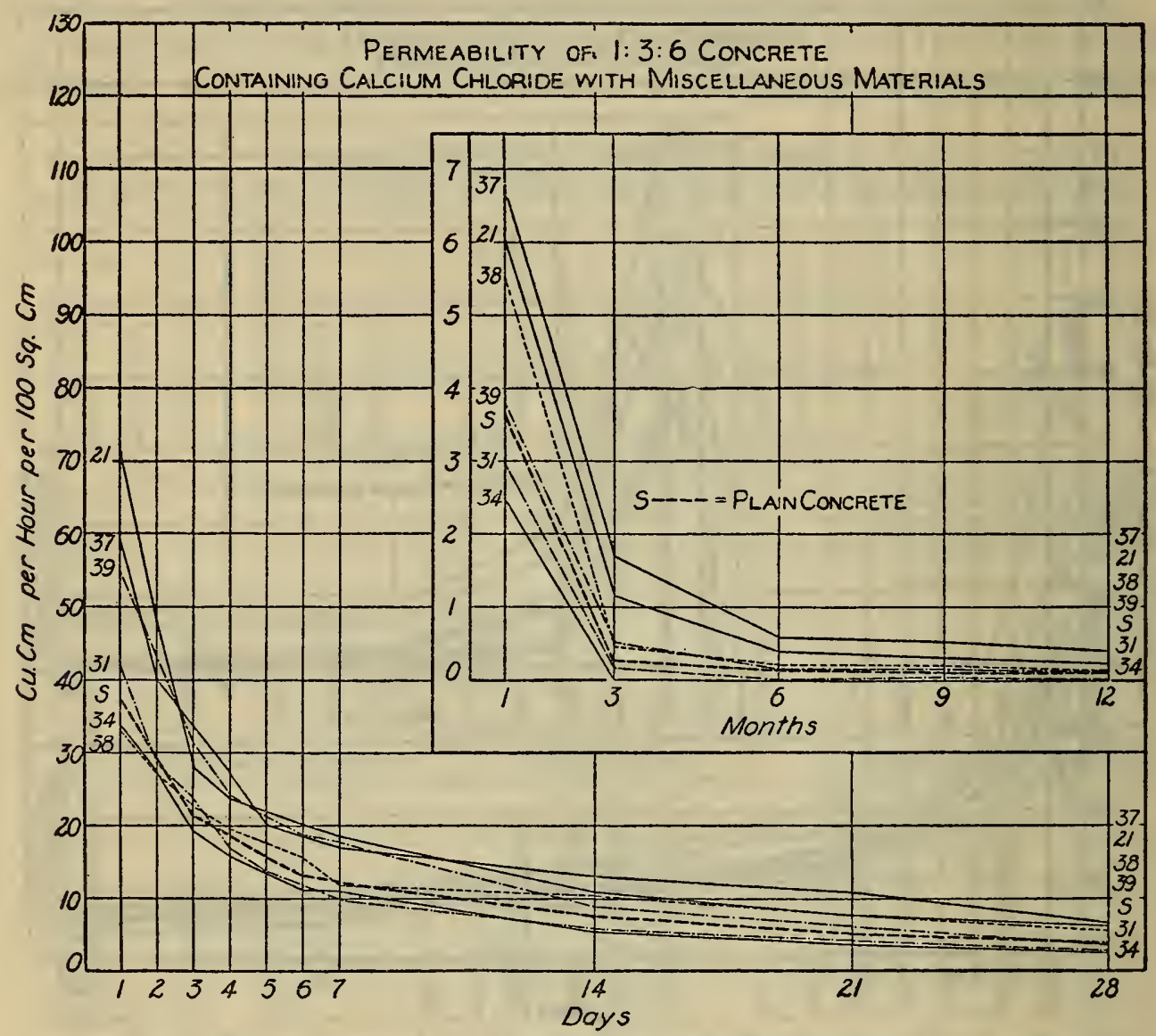

FIgURE 4.-Permeability of 1:3:6 concrete containing calcium chloride plus miscellaneous materials

hours. The other specimens did not vary appreciably from the standard.

When cured for one year, Nos. 21, 31, 34, and 39 caused a decrease in absorption for all periods. The decrease for these specimens was more marked in the later periods.

\section{GROUP CONTAINING SOAP (FIGS. 2 AND 5)}

Permeability.-Nos. $13,14,18,22,23,28$, and 36 are either pastes or liquids containing soaps of different compositions. The amount of each compound incorporated into the mix per bag of cement was approximately 2.2 pounds of No. $13,2.4$ pounds of No. 14, 1.5 pounds of No. 18, 2 pounds of No. 22, 2 pounds of No. 23, 2 pounds of No. 29 , and 2.1 pounds of No. 36 .

In all cases the concrete mixes containing these materials were more permeable than the standard except a decrease in permeability for 
the last period was shown by those containing less soap. Nos. 22 and 23 containing a high percentage of a stearate soap and No. 36 containing a relatively high percentage of an oleate soap did not show as great a decrease in permeability for the last period as was caused by the compounds containing smaller quantities of soaps. A marked decrease resulted with the use of Nos. 29 and 36 in permeability at three months and showing, but a small further decrease in the later periods. No. 36 containing more soap than No. 29 caused a greater permeability.

The permeability of the concrete containing these waterproofings was not appreciably affected by wire brushing.

Drying in the air of the laboratory for one month caused a marked increase in permeability at the end of 1-month test for concretes

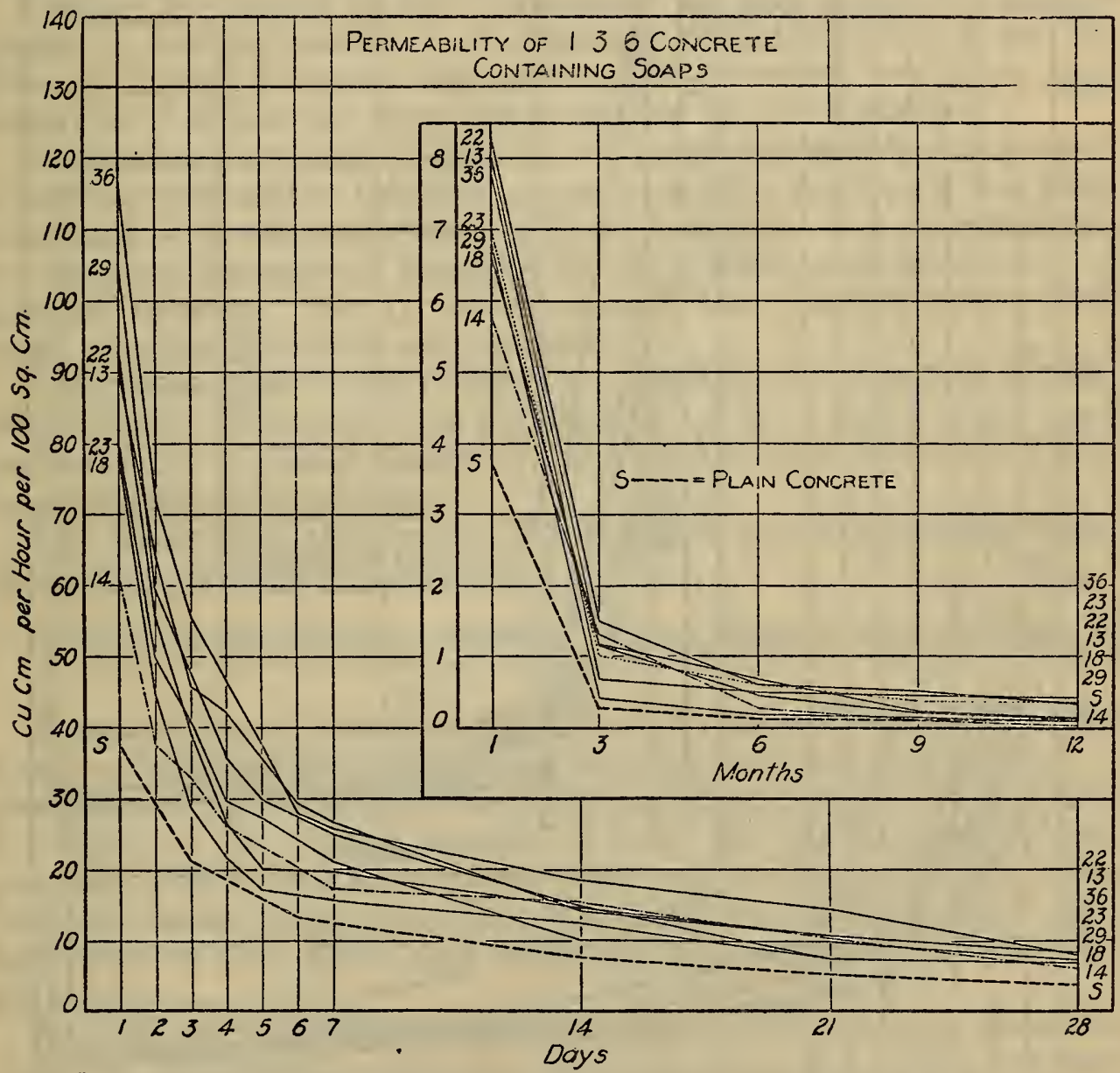

Figdre 5.-Permeability of $1: 3: 6$ concrete containing soaps

containing Nos. 29, 23, 36, and 18. Nos. 13, 14, and $2 \dot{2}$ gave results about the same as standard.

Compressive strength (Table 2).-This group showed a compressive strength at seven days slightly lower than that of the standard, except Nos. 13 and 22 which were the same as standard.

The 28-day strength was higher for No. 13; No. 14 was about the same as standard. The other samples caused a decrease in strength.

The 1-year strength of concrete containing waterproofings Nos. 13,22 , and 23 was about the same as standard. The other samples, however, gave strengths lower than the untreated concrete. 
Absorption after curing (Table 2).-The absorption of concrete containing these soaps was less than that of the standard for the first three periods, except in one instance. In the last two periods, No. 36 showed less absorption; the other samples were about the same as standard.

After curing for one year, Nos. 13, 29, and 36 caused a reduction in absorption for all periods, the reduction being quite appreciable

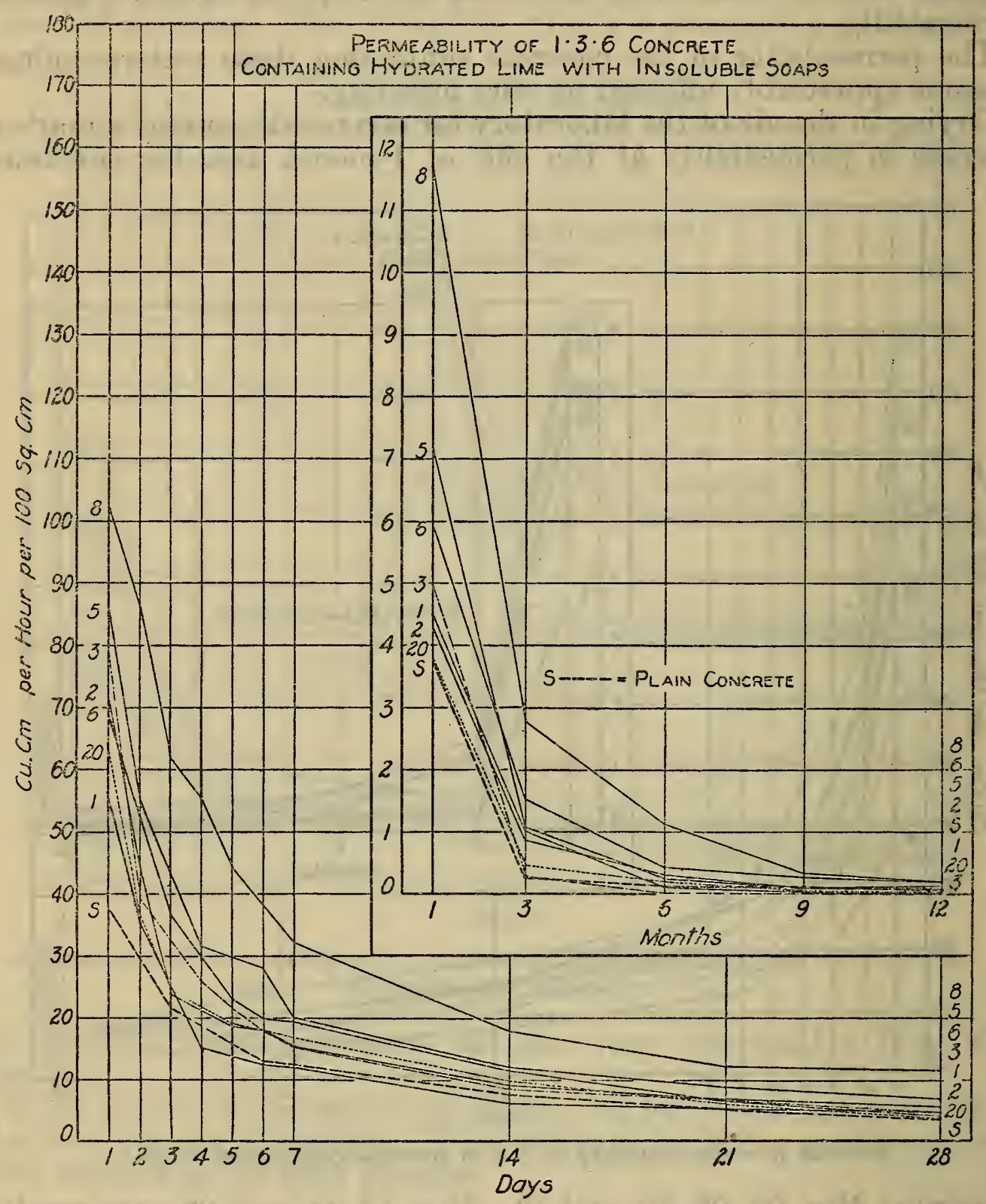

FIGURE 6.-Permeability of $1: 3: 6$ concrete containing hydrated lime with insoluble soaps

in the last two periods. The other samples showed only a slight deviation from the standard.

5. GROUP CONTAINING HYDRATED LIME AND SOAP (FIGS. 2 AND 6)

Permeability.-Waterproofings Nos. 1, 2, 3, 5, 6, and 8 are powders containing hydrated lime and varying quantities of insoluble soaps. No. 20 is a paste consisting of lime, alum, and an insoluble soap. 
The samples were incorporated into the mix in the following proportions per bag of cement: 2 pounds of Nos. 1, 3, 5 , and $6,1.9$ pounds of Nos. 2 and 8, and 1.5 quarts or approximately 3 pounds of No. 20 .

This group yielded concrete that gave a high initial permeability. This decreased rapidly for the first few days although No. 8 remained high in permeability for the entire test. The group in general shows a greater permeability than standard throughout the test, approaching the standard, however, at the end of the year. Concrete containing sample No. 1 is the only one that shows a permeability less than the standard and after 21 days it is about the same as standard for the remainder of the test.

The permeability of concrete containing these waterproofings was not affected by wire brushing.

Drying in the air of the laboratory for one month caused an increase in the permeability of concrete containing No. 6 and No. 8 . Nos. 1, 3, and 20 gave less permeable concrete, and Nos. 2 and 5 concrete of about the same permeability as the standard.

Compressive strength (Table 2).- The compressive strength of the concretes containing this group was generally decidedly less than the standard with the exception of Nos. 1 and 6 . No. 8, which caused the greatest decrease in strength for all periods, contained the greatest amount of soap. No. 6 , which showed the greatest strength at one year, was the lowest in soap content.

Absorption after curing (Table 1).-This group caused an appreciable reduction in absorption for all periods. Nos. 1 and 6 were more absorbent than the other samples in this group; they, however, contained smaller quantities of soap.

The absorption after curing for one year was appreciably less than that of the standard in most cases.

\section{GROUP CONTAINING FINELY SUBDIVIDED MATERIALS (FIGS. 2 AND 7)}

Permeability.-Waterproofings Nos. 9, 46, 47, 48, 49, and 50 are finely subdivided materials, such as silica, soapstone, lime, etc. They were added to the mix in the following amounts per bag of cement: 3 pounds of No. 9, 9.4 pounds of Nos. $46,47,49$, and 50, and 4.7 pounds of No. 48. No. 9 is the only one in this group which gave a concrete more permeable than the standard for all periods with the exception of No. 46 at one year, which showed an increase in permeability.

Nos. $46,47,48,49$, and 50 were appreciably lower in permeability than the standard for the first three months, and about the same as standard for the remainder of the test. The behavior of No. 46 for the last three months was abnormal.

Wire brushing caused an increase in the permeability of No. 49 . The others were not appreciably affected.

One month's drying in the air of the laboratory caused an abnormal increase in the permeability of No. 9. No. 47 was more permeable than the standard 24 hours after drying, but was approximately the same as standard at the end of a month. Nos. 46, 48, 49, and 50 were less permeable than the standard.

Compressive strength (Table 2).- The incorporation of these waterproofings in the mix gave, in general, a concrete with a strength equal to or greater than the standard. 
Absorption after curing (Table 2).-The absorption of concrete containing the materials in this group was practically the same as standard. After curing one year the absorption was considerably greater than that of the standard, with the exception of No. 9.

\section{GROUP CONTAINING MISCELLANEOUS MATERIALS (FIGS. 2, 8, AND 9)}

Permeability.-Waterproofings Nos. 4, 10, 15, 16, 17, 19, 40, 44, 45, $11,12,32$, and 43 are of various compositions. Nos. 42 and 41 are special cements, the latter containing calcium stearate. The amounts incorporated in the mix per bag of cement were approximately 1.9 pound of Nos. 4 and 19, 4.2 pounds of No. 10, 3.8 pounds of Nos. 15 and 16, 2.7 pounds of No. 17, 0.94 pounds of Nos. 40 and 43,4 pounds

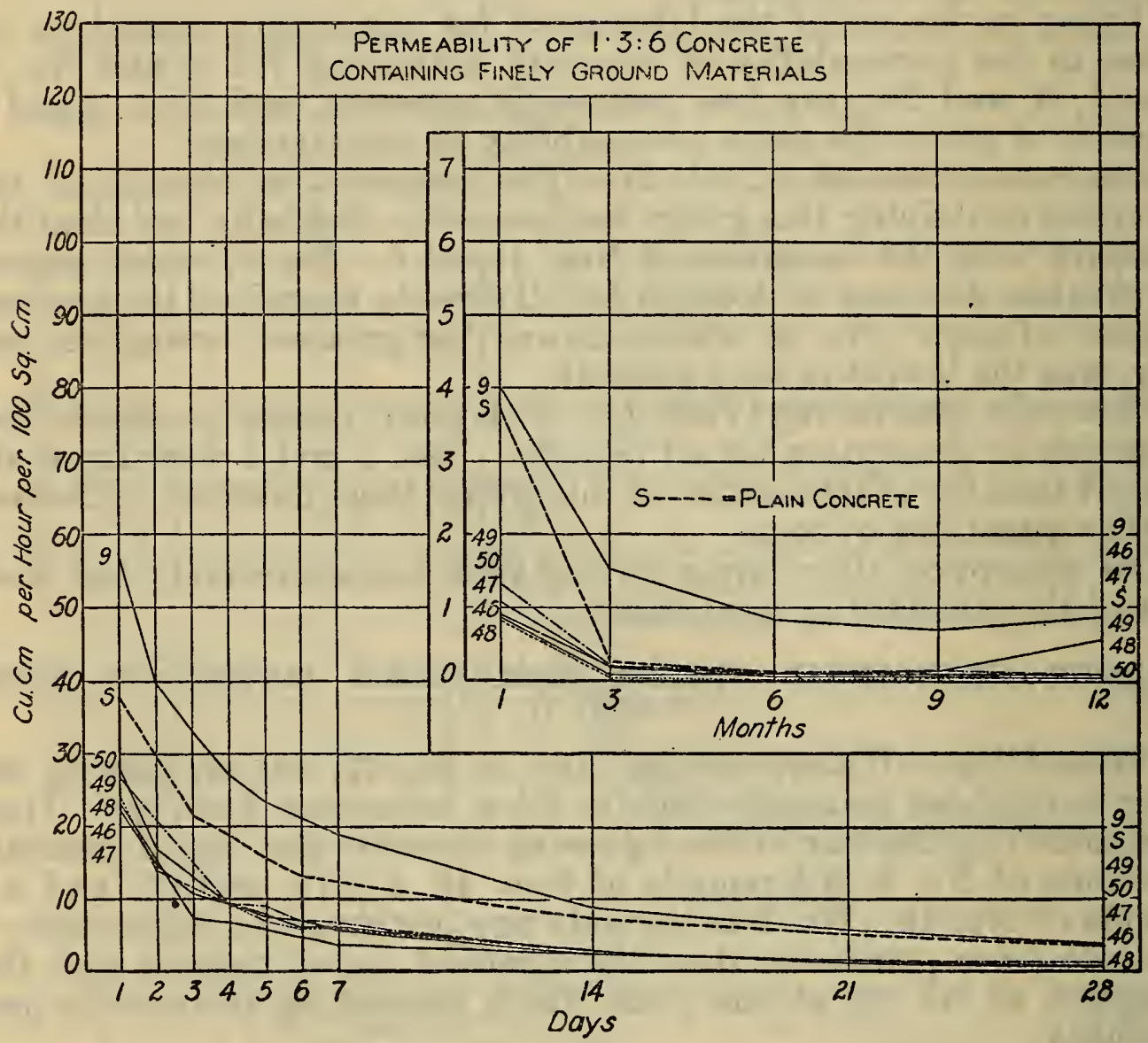

Frgure 7.-Permeability of 1:3:6 concrete containing finely ground materials

of No. 44, 1.2 pounds of No. 45, 21/4 pounds of No. 11, 1 pound of No. 12 and 2 pounds of No. 32 . Nos. 41 and 42 were used in place of the regular cement.

Nos. 4, 10, and 19 yielded concrete that was highly permeable at the start of the test, and remained so to the end of the test. No. 44 showed a marked decrease in permeability. No. 40 showed a higher initial permeability than the standard. This decreased equaling the standard at 14 days and was even less permeable for the remainder of the test. Nos. 15, 16, and 17 were of the same approximate composition. The specimens containing these three and No. 41 were more permeable than the standard at all periods. Nos. 42 and 45 yielded concretes that were less permeable for the first three months, 
and about the same as standard from three months to the end of the year. The concrete containing No. 11 was more permeable than the standard for the first three months and about the same as standard from that period until the end of the test. No. 12 yielded a concrete of about the same permeability as the standard; however, in the later periods the permeability increased slightly instead of normally decreasing in permeability. Concrete containing No. 43 was about

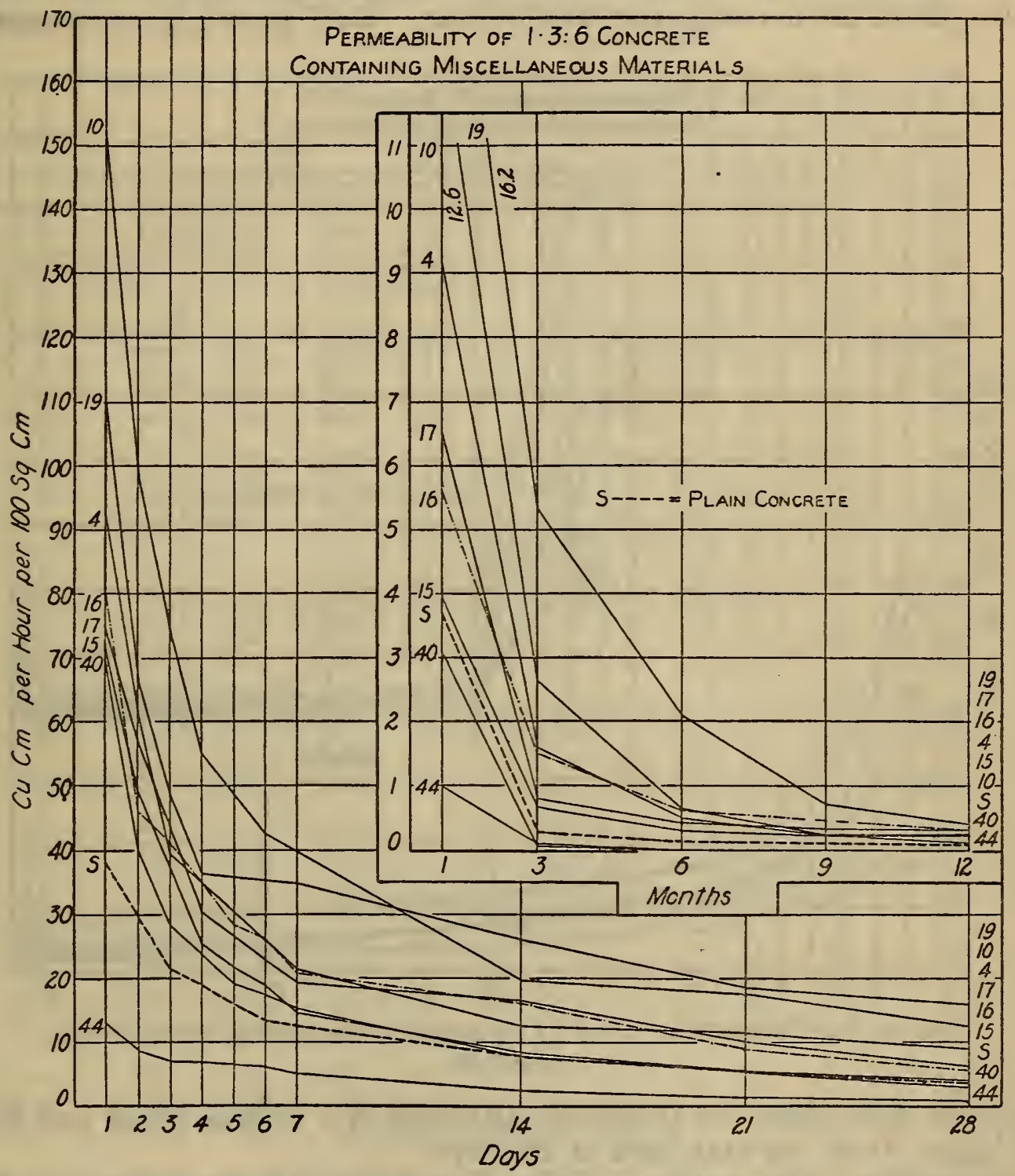

FIgURE 8.-Permeability of $1: 3: 6$ concrete coniaining miscellaneous materials

the same as standard. Concrete containing No. 32 was less permeable than the standard.

The concretes containing the samples of this group were not affected by wire brushing with the exception of No. 10 .

One month drying in the air of the laboratory caused a decided softening of the concrete containing No. 10. The permeability of Nos. $4,19,45,12,32$, and 42 were about the same as the standard. Nos. $15,16,17,11$, and 41 were more permeable than standard and Nos. 40,43 and 44 were less permeable. 
Compressive strength (Table 2).-The compressive strength of concrete containing the waterproofings in this group were generally lower than that of the standard. No. 10 showed a marked reduction in strength, yielding the lowest strength of all materials tested. No. 45 also showed an appreciable reduction in strength. Nos. 11 and 15 show strengths about the same as standard; Nos. 12 and 32 show a higher strength than standard at one year. Nos. 41 and 42 , which were special cements, gave lower strength than the cement used throughout the investigation at one year. Both gave higher strengths

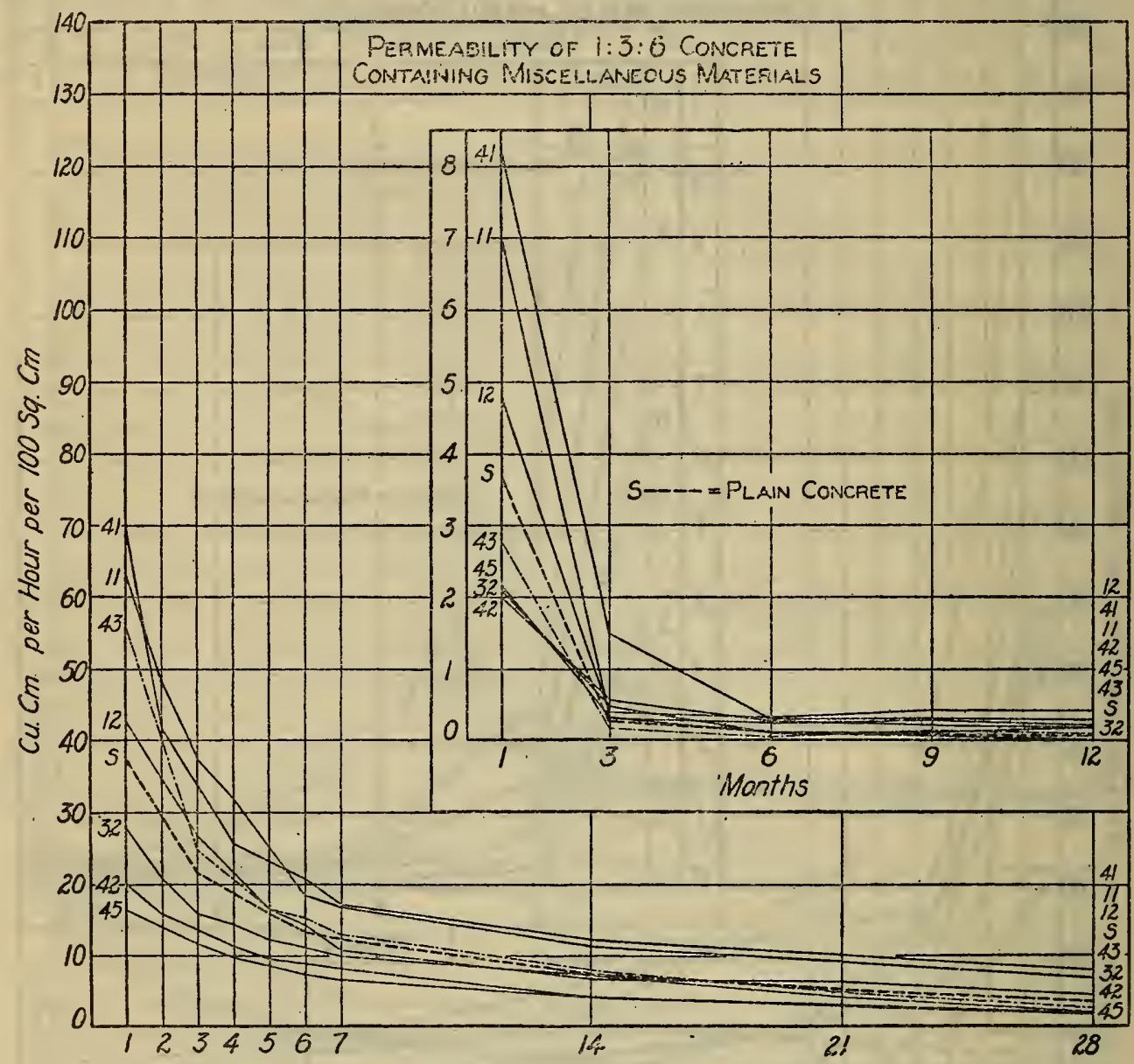

FIgURE 9.-Permeability of $1: 3: 6$ concrete containing miscellaneous materials

at seven days than the standard, although No. 41 was lower and No. 42 higher than the standard at 28 days.

Absorption after curing (Table 2). - With the exception of the concretes containing Nos. 40, 45, and 12 which showed about the same absorption as standard and Nos. 11 and 32 which were more absorbent than standard, the other waterproofings of this group caused a reduction in absorption of varying amounts. No. 43 gave the lowest absorption of all the waterproofings included in this investigation. After curing for one year the concrete containing Nos. $4,10,17,44,41$, and 43 showed a lower absorption than standard. Nos. 44 and 43 showed a marked reduction in absorption. Nos. 11 and 19 showed an increase in absorption. Nos. 12, 15, 16, and 45 caused a higher absorption for the first three periods and lower absorption for the last two periods. Nos. 32 and 42 were about the 
same as standard for the first two periods but less absorbent for the last three periods. No 40 was slightly lower for the early periods and slightly higher at 24 and 48 hours.

TABLE 2. $-1: 3: 6$ concrete containing integral waterproofing materials

\begin{tabular}{|c|c|c|c|c|c|c|c|c|c|c|c|c|c|}
\hline \multirow{3}{*}{ No. } & \multirow{2}{*}{\multicolumn{3}{|c|}{$\begin{array}{l}\text { Compressive strength, } 3 \text { by } \\
6 \text { inch cylinders }\end{array}$}} & \multicolumn{10}{|c|}{ Absorption, 3 by 6 inch cylinders } \\
\hline & & & & \multicolumn{5}{|c|}{ Cured 19 days } & \multicolumn{5}{|c|}{ Cured 1 year } \\
\hline & 7 days & 28 days & 1 year & $\begin{array}{c}1 \\
\text { hour }\end{array}$ & $\stackrel{2}{2}$ & $\begin{array}{c}4 \\
\text { hours }\end{array}$ & $\begin{array}{c}24 \\
\text { hours }\end{array}$ & $\begin{array}{c}48 \\
\text { hours }\end{array}$ & hour & $\stackrel{2}{\text { hours }}$ & $\stackrel{4}{4}$ & $\begin{array}{c}24 \\
\text { hours }\end{array}$ & $\begin{array}{c}48 \\
\text { hours }\end{array}$ \\
\hline & $\begin{array}{r}\text { Lbs. /in. } \\
840 \\
970 \\
1,100 \\
1,085 \\
1,070\end{array}$ & $\begin{array}{r}L b \varepsilon_{*} / \text { in } .2 \\
1,780 \\
1,910 \\
1,855 \\
2,075 \\
1,730\end{array}$ & $\begin{array}{r}\text { Lbs / in. }{ }^{2} \\
2,900 \\
3,000 \\
3,145 \\
3,220 \\
3,190\end{array}$ & $\begin{array}{l}P e r \\
c e n t \\
2.7 \\
2.0 \\
2.2 \\
1.9 \\
3.2\end{array}$ & $\begin{array}{r}P e r \\
\text { cent } \\
3.7 \\
3.1 \\
3.2 \\
3.0 \\
3.9\end{array}$ & \begin{tabular}{c|} 
Per \\
cent \\
4.8 \\
4.2 \\
4.4 \\
3.8 \\
5.0
\end{tabular} & $\begin{array}{l}\text { Per } \\
\text { cent } \\
5.3 \\
5.3 \\
5.4 \\
5.2 \\
5.3\end{array}$ & $\begin{array}{l}\text { Per } \\
\text { cent } \\
5.4 \\
5.4 \\
5.6 \\
5.3 \\
5.5\end{array}$ & $\begin{array}{r}\text { Per } \\
\text { cent } \\
0.9 \\
1.1 \\
.8 \\
.8 \\
.8\end{array}$ & $\begin{array}{r}\text { Per } \\
\text { cent } \\
1.1 \\
1.5 \\
1.1 \\
1.0 \\
1.0\end{array}$ & $\begin{array}{r}\text { Per } \\
\text { cent } \\
1.5 \\
1.9 \\
1.4 \\
1.2 \\
1.2\end{array}$ & $\begin{array}{r}P e r \\
c e n t \\
3.1 \\
4.0 \\
2.9 \\
2.4 \\
2.3\end{array}$ & $\begin{array}{r}\text { Per } \\
\text { cent } \\
3.9 \\
4.5 \\
3.8 \\
3.3 \\
2.8\end{array}$ \\
\hline & $\begin{array}{r}1,040 \\
1,085 \\
970 \\
965 \\
925\end{array}$ & $\begin{array}{l}1,775 \\
1,840 \\
1,750 \\
1,940 \\
1,555\end{array}$ & $\begin{array}{l}2,845 \\
3,125 \\
2,820 \\
2,970 \\
2,635\end{array}$ & $\begin{array}{l}2.4 \\
2.1 \\
3.4 \\
1.9 \\
2.2\end{array}$ & $\begin{array}{l}3.4 \\
3.6 \\
4.4 \\
2.8 \\
3.1\end{array}$ & $\begin{array}{l}4.5 \\
4.1 \\
5.1 \\
3.9 \\
4.1\end{array}$ & $\begin{array}{l}5.3 \\
5.3 \\
5.4 \\
5.2 \\
5.4\end{array}$ & $\begin{array}{l}5.3 \\
5.4 \\
5.4 \\
5.4 \\
5.5\end{array}$ & $\begin{array}{l}.8 \\
.9 \\
.8 \\
.8 \\
.8\end{array}$ & $\begin{array}{l}1.1 \\
1.1 \\
1.1 \\
1.0 \\
1.0\end{array}$ & $\begin{array}{l}1.4 \\
1.3 \\
1.4 \\
1.2 \\
1.3\end{array}$ & $\begin{array}{l}2.8 \\
2.3 \\
2.9 \\
2.4 \\
2.8\end{array}$ & $\begin{array}{l}3.7 \\
2.8 \\
3.9 \\
2.9 \\
3.6\end{array}$ \\
\hline & $\begin{array}{r}850 \\
765 \\
900 \\
1,125 \\
1,045\end{array}$ & $\begin{array}{l}1,830 \\
1,470 \\
1,880 \\
1,870 \\
1,775\end{array}$ & $\begin{array}{l}2,540 \\
2,240 \\
2,770 \\
3,165 \\
3,005\end{array}$ & $\begin{array}{l}1.5 \\
2.1 \\
1.7 \\
2.4 \\
2.3\end{array}$ & $\begin{array}{l}2.1 \\
3.2 \\
2.3 \\
3.4 \\
3.2\end{array}$ & $\begin{array}{l}2.7 \\
4.3 \\
3.1 \\
4.5 \\
4.3\end{array}$ & $\begin{array}{l}4.6 \\
5.3 \\
4.8 \\
5.3 \\
5.5\end{array}$ & & $\begin{array}{l}.8 \\
.6 \\
.9 \\
.7 \\
.9\end{array}$ & $\begin{array}{r}1.0 \\
.9 \\
1.2 \\
.8 \\
1.2\end{array}$ & $\begin{array}{l}1.2 \\
1.2 \\
1.5 \\
1.2 \\
1.5\end{array}$ & $\begin{array}{l}2.4 \\
2.3 \\
3.0 \\
2.5 \\
2.9\end{array}$ & $\begin{array}{l}3.1 \\
3.0 \\
3.6 \\
3.2 \\
3.7\end{array}$ \\
\hline & $\begin{array}{l}955 \\
715 \\
875 \\
775 \\
830\end{array}$ & $\begin{array}{l}1,780 \\
1,365 \\
2,015 \\
1,845 \\
1,605\end{array}$ & $\begin{array}{l}2,765 \\
2,000 \\
3,045 \\
2,380 \\
2,890\end{array}$ & $\begin{array}{l}1.8 \\
2.8 \\
1.8 \\
1.8 \\
1.9\end{array}$ & $\begin{array}{l}2.8 \\
3.5 \\
2.4 \\
2.4 \\
2.4\end{array}$ & $\begin{array}{l}3.9 \\
4.4 \\
3.0 \\
3.1 \\
3.2\end{array}$ & $\begin{array}{l}5.4 \\
5.0 \\
5.0 \\
4.9 \\
4.9\end{array}$ & $\begin{array}{l}5.5 \\
5.2 \\
5.2 \\
5.1 \\
5.2\end{array}$ & $\begin{array}{r}.8 \\
.6 \\
.7 \\
1.0 \\
1.0\end{array}$ & $\begin{array}{r}.9 \\
.8 \\
.9 \\
1.3 \\
1.3\end{array}$ & $\begin{array}{l}1.2 \\
.9 \\
1.2 \\
1.7 \\
1.6\end{array}$ & $\begin{array}{l}2.7 \\
2.0 \\
2.1 \\
3.3 \\
3.0\end{array}$ & $\begin{array}{l}3.8 \\
2.8 \\
2.5 \\
3.8 \\
3.6\end{array}$ \\
\hline & $\begin{array}{l}710 \\
555 \\
695 \\
810 \\
790\end{array}$ & $\begin{array}{l}1,695 \\
1,420 \\
1,380 \\
1,705 \\
1,535\end{array}$ & $\begin{array}{l}2,745 \\
2,045 \\
2,040 \\
2,775 \\
2,320\end{array}$ & $\begin{array}{l}1.9 \\
1.3 \\
1.9 \\
2.3 \\
1.7\end{array}$ & $\begin{array}{l}2.6 \\
2.0 \\
2.7 \\
3.0 \\
2.3\end{array}$ & $\begin{array}{l}3.5 \\
2.4 \\
3.5 \\
3.8 \\
3.0\end{array}$ & $\begin{array}{l}5.3 \\
3.8 \\
4.8 \\
5.2 \\
4.5\end{array}$ & & $\begin{array}{l}.9 \\
.7 \\
.8 \\
.8\end{array}$ & $\begin{array}{r}1.2 \\
1.0 \\
1.0 \\
1.0 \\
.8\end{array}$ & $\begin{array}{l}1.5 \\
1.2 \\
1.3 \\
1.6 \\
1.0\end{array}$ & $\begin{array}{l}3.2 \\
2.1 \\
2.5 \\
3.3 \\
2.2\end{array}$ & $\begin{array}{l}3.8 \\
2.6 \\
3.1 \\
3.8 \\
3.0\end{array}$ \\
\hline & $\begin{array}{l}930 \\
765 \\
880 \\
530 \\
735\end{array}$ & $\begin{array}{r}1,530 \\
1,365 \\
1,505 \\
875 \\
1,320\end{array}$ & $\begin{array}{l}2,410 \\
2,100 \\
2,010 \\
1,525 \\
2,105\end{array}$ & $\begin{array}{l}1.7 \\
1.7 \\
2.1 \\
1.7 \\
1.6\end{array}$ & $\begin{array}{l}2.2 \\
2.1 \\
3.0 \\
2.1 \\
2.1\end{array}$ & $\begin{array}{l}2.8 \\
2.6 \\
4.0 \\
2.7 \\
2.7\end{array}$ & $\begin{array}{l}3.9 \\
4.0 \\
5.0 \\
4.3 \\
4.3\end{array}$ & $\begin{array}{l}4.7 \\
4.2 \\
5.1 \\
4.7 \\
4.6\end{array}$ & $\begin{array}{l}.6 \\
.7 \\
.8 \\
.7 \\
.8\end{array}$ & $\begin{array}{r}.8 \\
.8 \\
1.0 \\
.9 \\
1.1\end{array}$ & $\begin{array}{l}1.0 \\
1.0 \\
1.3 \\
1.0 \\
1.4\end{array}$ & $\begin{array}{l}2.1 \\
2.0 \\
2.8 \\
2.0 \\
2.7\end{array}$ & $\begin{array}{l}2.7 \\
2.4 \\
3.4 \\
2.6 \\
3.4\end{array}$ \\
\hline & $\begin{array}{r}905 \\
1,170 \\
1,080 \\
970 \\
830\end{array}$ & $\begin{array}{l}1,860 \\
1,840 \\
1,965 \\
1,825 \\
1,800\end{array}$ & $\begin{array}{l}3,330 \\
3,300 \\
3,535 \\
3,020 \\
2,970\end{array}$ & $\begin{array}{l}2.5 \\
2.5 \\
2.4 \\
2.7 \\
2.7\end{array}$ & $\begin{array}{l}3.5 \\
3.4 \\
3.3 \\
3.7 \\
3.7\end{array}$ & $\begin{array}{l}4.3 \\
4.2 \\
4.1 \\
4.8 \\
4.7\end{array}$ & & & $\begin{array}{r}.9 \\
1.5 \\
1.3 \\
1.5 \\
1.4\end{array}$ & $\begin{array}{l}1.2 \\
2.0 \\
1.7 \\
2.0 \\
1.8\end{array}$ & & & $\begin{array}{r}4.1 \\
4.0 \\
4.1 \\
4.6 \\
4.6\end{array}$ \\
\hline & $\begin{array}{l}790 \\
810 \\
610 \\
240\end{array}$ & $\begin{array}{r}1,655 \\
1,565 \\
1,100 \\
455\end{array}$ & $\begin{array}{r}2,940 \\
2,390 \\
1,790 \\
870\end{array}$ & $\begin{array}{l}2.8 \\
1.9 \\
1.7 \\
1.7\end{array}$ & $\begin{array}{l}3.7 \\
2.5 \\
2.5 \\
2.0\end{array}$ & $\begin{array}{l}4.8 \\
3.1 \\
3.4 \\
2.5\end{array}$ & $\begin{array}{l}5.3 \\
4.4 \\
5.0 \\
3.8\end{array}$ & $\begin{array}{l}5.3 \\
4.7 \\
5.1 \\
4.0\end{array}$ & $\begin{array}{r}1.5 \\
.7 \\
1.0 \\
.8\end{array}$ & $\begin{array}{r}1.8 \\
.9 \\
1.3 \\
1.0\end{array}$ & $\begin{array}{l}2.3 \\
1.1 \\
1.7 \\
1.1\end{array}$ & $\begin{array}{l}4.0 \\
2.3 \\
3.5 \\
1.9\end{array}$ & $\begin{array}{l}4.5 \\
2.9 \\
4.2 \\
2.3\end{array}$ \\
\hline & $\begin{array}{l}845 \\
735 \\
780 \\
785\end{array}$ & $\begin{array}{l}1,705 \\
1,700 \\
1,725 \\
1,470\end{array}$ & $\begin{array}{l}2,990 \\
2,750 \\
2,750 \\
2,290\end{array}$ & $\begin{array}{l}1.0 \\
1.7 \\
1.5 \\
2.4\end{array}$ & $\begin{array}{l}1.9 \\
2.2 \\
2.0 \\
3.5\end{array}$ & $\begin{array}{l}2.5 \\
2.7 \\
2.5 \\
4.8\end{array}$ & $\begin{array}{l}3.6 \\
4.0 \\
3.9 \\
5.4\end{array}$ & $\begin{array}{l}4.0 \\
4.5 \\
4.3 \\
5.6\end{array}$ & $\begin{array}{r}1.0 \\
1.2 \\
.8 \\
.8\end{array}$ & $\begin{array}{l}1.3 \\
1.3 \\
1.0 \\
1.0\end{array}$ & $\begin{array}{l}1.6 \\
1.7 \\
1.2 \\
1.4\end{array}$ & $\begin{array}{l}2.7 \\
3.1 \\
2.1 \\
3.4\end{array}$ & $\begin{array}{l}3.1 \\
3.6 \\
2.4 \\
4.2\end{array}$ \\
\hline & $\begin{array}{l}645 \\
515 \\
720 \\
775\end{array}$ & $\begin{array}{r}1,480 \\
970 \\
1,775 \\
1,700\end{array}$ & $\begin{array}{l}2,535 \\
1,640 \\
2,885 \\
3,050\end{array}$ & $\begin{array}{l}1.4 \\
3.2 \\
3.1 \\
2.9\end{array}$ & $\begin{array}{l}1.9 \\
3.8 \\
4.1 \\
3.7\end{array}$ & $\begin{array}{l}2.2 \\
4.3 \\
5.0 \\
4.9\end{array}$ & $\begin{array}{l}3.8 \\
5.0 \\
5.3 \\
5.2\end{array}$ & $\begin{array}{l}4.5 \\
5.2 \\
5.4 \\
5.3\end{array}$ & $\begin{array}{l}.5 \\
1.2 \\
1.0 \\
1.1\end{array}$ & $\begin{array}{r}.7 \\
1.6 \\
1.5 \\
1.4\end{array}$ & $\begin{array}{l}.8 \\
1.9 \\
1.8 \\
1.6\end{array}$ & $\begin{array}{l}1.4 \\
2.6 \\
3.3 \\
2.6\end{array}$ & $\begin{array}{l}1.7 \\
3.9 \\
3.8 \\
3.1\end{array}$ \\
\hline 4 & $\begin{array}{r}820 \\
1,080 \\
1,510 \\
915\end{array}$ & $\begin{array}{l}1,805 \\
1,570 \\
2,130 \\
1,520\end{array}$ & $\begin{array}{l}3,160 \\
2,195 \\
2,760 \\
2,610\end{array}$ & $\begin{array}{r}3.5 \\
1.4 \\
1.6 \\
.7\end{array}$ & $\begin{array}{l}4.6 \\
1.8 \\
2.3 \\
.9\end{array}$ & $\begin{array}{l}5.3 \\
2.4 \\
3.2 \\
1,1\end{array}$ & $\begin{array}{l}5.5 \\
4.1 \\
4.9 \\
2.2\end{array}$ & $\begin{array}{l}5.5 \\
4.4 \\
5.1 \\
2.8\end{array}$ & $\begin{array}{l}.9 \\
.7 \\
.9 \\
.5\end{array}$ & $\begin{array}{r}1.1 \\
1.9 \\
1.1\end{array}$ & $\begin{array}{r}1.3 \\
1.1 \\
1.3 \\
.6\end{array}$ & $\begin{array}{l}2.7 \\
2.0 \\
2.4 \\
1.0\end{array}$ & $\begin{array}{l}3.4 \\
2.5 \\
2.9 \\
1.2\end{array}$ \\
\hline
\end{tabular}




\section{SUMMARY (INTEGRAL WATERPROOFING)}

1. The addition of calcium chloride to the $1: 3: 6 \mathrm{mix}$ of concrete used in this study did not materially reduce its permeability or absorption. It did, however, seem to increase the compressive strength. An increase in the amount of calcium chloride added per bag of cement seemed to decrease the initial permeability.

2. The incorporation of such materials as soap, silica, and aluminum chloride, with calcium chloride in concrete did not reduce the permeability.

3. The presence of soap in addition to calcium chloride caused a reduction in absorption.

4. The usual increase in strength due to calcium chloride was not obtained when soap was present with the chloride.

5. The addition of soap alone to the concrete caused an increase in permeability. The strength of the concrete containing oleate soap was appreciably reduced. In general, the presence of soaps in concrete caused a reduction in absorption; also a higher initial permeability than the other waterproofings used.

6 . Hydrated lime mixed with soap and then incorporated in the concrete gave a higher permeability than the standard. It was not as high as when soaps were added alone. The presence of an appreciable quantity of soap and lime in concrete lowered the strength and reduced the absorption.

7. The finely subdivided compounds used as fillers in general reduced the permeability and in general increased the compressive strength. The absorption was about the same or greater than standard.

8. The permeability of concrete was not reduced by the addition of such miscellaneous materials as cellulose and wax, or by the addition of materials containing uncombined fatty acids, fluosilicate, naphthalene, vaseline, butyl stearate, or coal tar. These compounds in general lowered the compressive strength but reduced the absorption. The presence of a mixture of heavy mineral oil and a saponifiable oil reduced the permeability, absorption, and also the strength.

In the above summary the statements are somewhat general and apply more particularly to the results as obtained for all the materials in any group. Close study shows that the individual waterproofings in a group may vary considerably in their properties.

\section{METHOD OF FABRICATION AND TEST OF SURFACE WATERPROOFING}

For this part of the investigation a number of 3 by 6 inch concrete cylinders were made. A 1:2:4 mix by volume of Portland cement (meeting the requirements of the United States Government), Potomac River sand, and a gravel graded between No. 4 and three-eighths inch was used with a water-cement ratio of 1.00 by volume. Weighed portions of cement, sand, and gravel were thoroughly mixed in a galvanized iron pan, the water then added and the mixing continued for two minutes. The concrete was then placed in the molds in three layers, each layer being rodded 25 times with a blunt end tamping rod. The surplus was struck off flush with the top of the mold. After 24 hours the forms were removed and the entire surfaces of the cylinders were wire brushed. They were then placed in the damp closet for 
curing. At the age of 7 days the specimens were placed on shelves in the laboratory where the air could freely circulate around all surfaces. They were weighed after 14 days in the air and then weighed every day until they reached constant weight. Three cylinders were coated with each of the surface waterproofing materials and placed on the shelves in the laboratory and allowed to dry to constant weight. They were then totally immersed in water and weighed at 15 minutes, 1 hour, 2 hours, 4 hours, 24 hours, 48 hours, 72 hours, and each succeeding week for one year. The cylinders were then placed on the shelves of the laboratory for one month, again weighed and immersed in water. Weighings were made on the cylinders so treated at 15 minutes, 1 hour, 2 hours, 24 hours, 48 hours, 72 hours, 1 week, and each succeeding week until 2 months old and again at 9 months. Several uncoated cylinders were dried to constant weight, immersed in water and weighed at the same intervals of time as the coated cylinders.

The absorption was computed from the recorded weights, and is reported in per cent of the dry weight. The results obtained on the three cylinders from each mix were averaged and are presented in Table 4.

No specimens were prepared, as in the study of the integral waterproofings, which were tested under a head. It was assumed that if a material allowed water to penetrate into the treated specimen when immersed in water, it would also be permeable under any greater head. The procedure adopted gave a good value for rate of penetration of water through the applied waterproofing mediums. Further, since practically all of the materials sooner or later showed marked permeability, this simple test procedure seems to have been adequate. It does not indicate, however, that the few materials which appear to be satisfactory at the end of a year, might not have shown considerable permeability under some head.

No membranes composed of alternate layers of felt, burlap, etc., and bituminous products, were included in this study. This method of waterproofing although undoubtedly the most costly one, is so universally acknowledged as being satisfactory that it was not deemed necessary to consider it.

This study of coatings was confined to their use between the source of water and the concrete and not to the case where the concrete is between the source and the coating. In other words, the coatings were considered on the same basis as the integral waterproofings, namely, original means of keeping concrete water-tight applied approximately at the time of making the concrete, and not remedial means applied some time in the later life of the concrete when unanticipated leakage has occurred. This special case of waterproofing has not been considered at all. 


\section{SURFACE WATERPROOFING MATERIALS}

\section{COMMERCIAL NAMES}

The materials used in this investigation were furnished by the manufacturer under the following trade names:

Am. Builders' Transparent Waterproofing (A. B. -6).

Am. Builders' Plaster Bond (A. B.-5). Anti Hydro.

Aquabar Clear Coat No. 2.

Aquabar Elastic Cement Coating No. 6.

Aquabar Mastic Cement.

Aquanox No. 202.

Butyl Stearate.

Butyl Oleate.

Cresolac Transparent Waterproofer.

Dehydratine No. 2.

Dibutyl Phthalate.

General Fireproofing Ironcote (G. F. 14).

General Fireproofing Brush Coating (G. F. 16).

General Fireproofing Bonding Compound (G. F. 400).

General Fireproofing Transparent Waterproofing (G. F. 100).

Hetzel's Fibrous Roof Koting.

Hydrocide Colorless Liquid A.

Hydroseal No. 640.

Ironite.

Isolite.

Konkerit Primer (liquid).

Konkerit (liquid)

Linseed oil (boiled).

Master Builders' Efflorex.
Master Builders' Masterseal No. 1.

Master Builders' Metallic Waterproofing.

Minwax Clear.

Minwax Clear (heavy).

Minwax Colorless (heavy).

Mortex No. 5.

Mortex No. 5A.

Mortex No. 5B.

Mortex No. 10 Fibrated.

Mortex No. 10 Mastic.

Mortex No. 20.

Mulsomastic.

Penetrite Transparent Compound No. 1.

Penetrite Transparent Compound No. 2.

Protex No. 22.

Protex No. 88.

Protone.

R. O. P. Cement Coating.

R. O. P. Damp Resisting Paint.

Silicate of Soda (concrete special).

Transkote.

Tricosal Normal.

Tricosal S III.

Toxloxpore.

Wa-Co Surface Waterproofing.

Whigelt's Xterior Waterproofing.

\section{COMPOSITION AND METHOD OF APPLICATION}

The surface waterproofings are grouped in accordance with their chemical compositions. The first group represents those containing asphalt emulsions; the second group, bituminous solutions; the third, finely ground iron; the fourth, cement coatings; the fifth, transparent coatings; and the sixth, paint and varnish coatings.

The composition and method of application are given briefly in Table 3. 
TABLE 3.-Composition and method of application of surface waterproofing material Group No. 1. ASPHALT EMULSIONS

\begin{tabular}{|c|c|c|}
\hline $\begin{array}{l}\text { Mate- } \\
\text { rial No. }\end{array}$ & Composition & Method of application \\
\hline 5 & $\begin{array}{l}\text { First coat a clay asphalt emulsion; second coat } \\
\text { a clay asphalt emulsion containing asbestos. }\end{array}$ & $\begin{array}{l}\text { First coat diluted with } 25 \text { per cent water; } \\
\text { second coat applied with a trowel to a thick- } \\
\text { ness of one-sixteenth inch after first coat was } \\
\text { dry. }\end{array}$ \\
\hline 6 & Clay asphalt emulsion containing asbestos....... & $\begin{array}{l}\text { First coat was No. } 8 \text { diluted with } 25 \text { per cent of } \\
\text { water; second coat was No. } 6 \text { applied with a } \\
\text { trowel } 6 \text { hours after No. } 8 \text {. }\end{array}$ \\
\hline $\begin{array}{l}7 \\
8\end{array}$ & Clay asphalt emulsion & $\begin{array}{l}2 \text { coats brushed on } 24 \text { hours apart. } \\
\text { First coat thinned with } 10 \text { per cent water; } \\
\text { 3econd coat applied full strength } 24 \text { hours } \\
\text { later. }\end{array}$ \\
\hline $\begin{array}{r}9 \\
10\end{array}$ & & $\begin{array}{l}\text { Applied same as No. } 8 \text {. } \\
\text { Do. }\end{array}$ \\
\hline 13 & (n) & $\begin{array}{l}\text { First coat thinned with } 20 \text { per cent water; } \\
\text { second coat applied full strength } 24 \text { hours } \\
\text { later. }\end{array}$ \\
\hline 41 & Clay asphalt alcohol emulsion & 2 coats flowed on 24 hours apart. \\
\hline 42 & $\begin{array}{l}\text { Clay asphalt alcohol emulsion containing small } \\
\text { amount of calcium chloride. }\end{array}$ & $\begin{array}{l}\text { The concrete was saturated with water and a } \\
\text { thin coat of No. } 42 \text { mixed with water to a } \\
\text { creamy consistency was applied. The second } \\
\text { coat was neat cement thinned to a creamy con- } \\
\text { sistency with a solution of half each of No. } 42 \\
\text { and water; topping coat floated on consisting } \\
\text { of } 1 \text { part Portland cement and } 2 \text { parts of sand } \\
\text { wet with a solution of half each of No. } 42 \text { and } \\
\text { water. When sufficiently set, the surface was } \\
\text { troweled and kept under damp cloth for } 48 \\
\text { hours. }\end{array}$ \\
\hline
\end{tabular}

Group No. 2. BITUMINOUS SOLUTIONS

16 Asphalt cut in petroluem spirits 74 per cent nonvolatile.

18 Asphalt cut in petroleum spirits 57 per cent nonvolatile.

21 Asphalt cut in petroleum spirits 67 per cent nonvolatile.

23 Mixture of asbestos, asphalt, and petroleum spirits containing 45 per cent asbestos, 50 per cent asphalt, and 5 per cent petroleum spirits. Asphalt cut in petroleum spirits 75 per cent nonvolatile. Small amount of asbestos.

31 Asphalt cut in petroleum spirits 60 per cent nonvolatile.
2 brush coats 4 days apart.

2 brush coats 24 hours apart.

Do.

1 coat applied one-eighth to one-fourth inch thick.

1 coat brushed on.

Do.

\section{Group No. 3. FINELY GROUND IRON}

Finely ground iron and sal ammoniac.

27

43

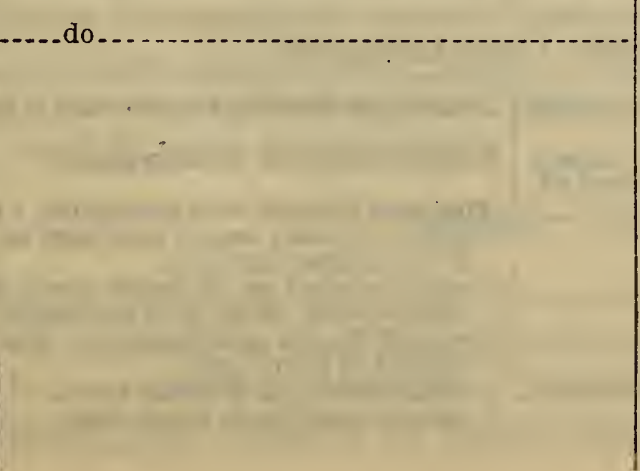

Surface treated with solution of magnesium chloride. No. 17 mixed with water to a whitewash consistency and applied to $a$ well-wetted surface. The surface was then gently wetted during the first day as often as the surface became dry. The 4 succeeding coats were a little thicker and were applied the same as the first coat.

The surface was saturated with water for 24 hours. Brush coat applied consisting of equal parts of No. 27 and Portland cement of the consistency of heavy paint. This was immediately followed by a plastic coat oneeighth inch thick consisting of No. 27, sand and Portland cement in equal parts by weight.

Surface thoroughly wet with water. Brush coat then applied of No. 43 thinned with water to a thick paste. Dry in air for 24 hours; wet down with water 4 times during that period. Second coat applied in same manner as flrst coat. Third coat, consisting of 1 part Portland cement, three-fourths part of sand and one-fifth part of No. 43 mixed with water to a consistency a little thinner than plaster, is brushed on the wet surface. Allowed to set in air for 24 hours, being wet down several times during that period. Fourth coat, consisting of 1 part of cement and three-fourths part of sand mired with water to a slush a little thinner than plaster, applied to wet surface. Dry in open air 24 hours, being wet down several time during that period. 
TABLE 3.-Composition and method of application of surface waterproofing

Group No. 4. CEMENT COATINGS

\begin{tabular}{|c|c|c|}
\hline $\begin{array}{l}\text { Mate- } \\
\text { rial No. }\end{array}$ & Composition & Method of application \\
\hline 47 & $\begin{array}{l}\text { Light yellow colored liquid contains about } 73 \\
\text { per cent of water; remainder calcium chloride } \\
\text { and less than } 1 \text { per cent of saponifiable resin- } \\
\text { ous material. }\end{array}$ & $\begin{array}{l}3 \text { coats of the following mix were applied: } 1 \text { gal- } \\
\text { lon No. } 47,3 \text { gallons of water and a hall bag of } \\
\text { Portland cement. }\end{array}$ \\
\hline 48 & $\begin{array}{l}\text { Clear amber colored liquid acid in reaction. } \\
\text { Contains about } 70 \text { per cent water; remainder } \\
\text { calcium chloride, aluminum chloride, and } \\
\text { small amount of organic matter. }\end{array}$ & $\begin{array}{l}1 \text { coat of the following mix was applied with a } \\
\text { trowel: } 1 \text { part of cement to } 11 / 2 \text { parts of sand } \\
\text { mixed with a } 1: 1 \text { solution of No. } 48 \text { and water. }\end{array}$ \\
\hline 49 & $\begin{array}{l}\text { Thick brown liquid with an odor of glue. Con- } \\
\text { tains sodium silicate and an organic nitrog- } \\
\text { enous material resembling glue. }\end{array}$ & $\begin{array}{l}1 \text { coat of the following mix was applied with a } \\
\text { trowel: } 1 \text { part of cement and } 11 / 2 \text { parts of sand } \\
\text { mixed with a solution of No. } 49 \text { to } 30 \text { parts of } \\
\text { water. }\end{array}$ \\
\hline
\end{tabular}

Group No. 5. TRANSPARENT COATINGS

\begin{tabular}{|c|c|c|}
\hline 1 & $\begin{array}{l}\text { Brown colored liquid. Contains glycol, water, } \\
\text { ammonia, alcohol, and unsaponifiable oil. }\end{array}$ & 2 coats 48 hours apart. \\
\hline 2 & Butyl stearate. & 3 coats brushed on 24 hours apart. \\
\hline 3 & Butyl oleate & Do. \\
\hline 4 & Dibutyl phthalate & Do. \\
\hline 11 & Boiled linseed cil & $\begin{array}{l}2 \text { coats brushed on } 24 \text { hours apart; third coat } 3 \\
\text { days later. }\end{array}$ \\
\hline 46 & $\begin{array}{l}\text { Dark brown oily liquid. Is a mixture of non- } \\
\text { drying fatty oils and mineral oil. }\end{array}$ & 1 coat brushed on. \\
\hline 25 & $\begin{array}{l}\text { Turbid oily liquid. Contains a nondrying oil, } \\
\text { paraffin, and mineral oil. }\end{array}$ & 2 coats brushed on 24 hours apart. \\
\hline 37 & China wood oil cut in mineral spirits & Do. \\
\hline 12 & $\begin{array}{l}\text { Lemon-colored turbid oily liquid. Contains } \\
\text { mineral oil, a semihard grease similar to } \\
\text { vaseline and a small amount of a saponifiable } \\
\text { oil. }\end{array}$ & 2 coats brushed on 48 hours apart. \\
\hline 15 & $\begin{array}{l}\text { Turbid oily solution. Contains saponifiable } \\
\text { material cut in mineral oil. }\end{array}$ & 2 coats brushed on 24 hours a part. \\
\hline 24 & $\begin{array}{l}\text { Clear light-colored oil. Contains mineral wax } \\
\text { dissolved in mineral oil and a small amount } \\
\text { of nitrobenzene. }\end{array}$ & 3 coats brushed on 24 hours apart. \\
\hline 26 & $\begin{array}{l}\text { Light yellow colored oil. Contains paraffin } \\
\text { wax cut in light mineral oil. }\end{array}$ & 2 coats brushed on 24 hours apart. \\
\hline 28 & $\begin{array}{l}\text { Thick viscous liquid. Benzol solution of a } \\
\text { semihard material, partially saponifiable and } \\
\text { mineral oil. }\end{array}$ & Do. \\
\hline 32 & $\begin{array}{l}\text { Clear oily solution. Contains mineral wax cut } \\
\text { in petroleum spirits. }\end{array}$ & 2 coats brushed on 48 hours apart. \\
\hline 35 & $\begin{array}{l}\text { Clear solution with a white precipitate. Con- } \\
\text { tains a saponifiable material cut in petro- } \\
\text { leum spirits. }\end{array}$ & 2 coats brushed on 24 hours apart. \\
\hline 38 & $\begin{array}{l}\text { Light yellow colored oil. Contains saponifiable } \\
\text { material and paraffin dissolved in low boil- } \\
\text { ing mineral spirits. }\end{array}$ & Do. \\
\hline 39 & $\begin{array}{l}\text { Light yellow colored oil. Quite similar to } \\
\text { No. 38. Contains less parafin and larger } \\
\text { quantity of saponifiable material than No. } 38 \text {. }\end{array}$ & Do. \\
\hline 40 & $\begin{array}{l}\text { Light yellow colored liquid. Contains a } \\
\text { small amount of saponifiable material and } \\
\text { paraffin cut in mineral oil. }\end{array}$ & Do. \\
\hline 36 & $\begin{array}{l}\text { Clear lemon-colored solution. Contains a } \\
\text { saponifiable material cut in turpentine and } \\
\text { mineral spirits. }\end{array}$ & Do. \\
\hline 19 & $\begin{array}{l}\text { White turbid water solution. Contains a } \\
\text { saponifiable material and sodium stearate. }\end{array}$ & 3 coats brushed on 24 hours apart. \\
\hline 50 & Solution of sodium silicate. & $\begin{array}{l}3 \text { coats applied of a } 1: 4 \text { solution of } N o .50 \text { and } \\
\text { water, } 24 \text { hours between coats. }\end{array}$ \\
\hline
\end{tabular}

\section{Group No. 6. PAINTS AND VARNISHES}

14 Thick gray gelatinous paste. Contains varnish and asbestos.

20 Dark-colored oily liquid. Contains mineral oil and a saponifiable oil similar to linseed oil. White lead oil paint.
Material as received applied with a trowel. 2 coats brushed on 24 hours apart.

First coat thinned with turpentine, 1 pint to 1 gallon of paint; second coat used as received 48 hours after first coat.

2 coats brushed on 24 hours apart; first coat thinned with 20 per cent turpentine.

1 coat of No. 33 and 2 coats of No. 34 were applied 24 hours apart.

2 coats brushed on 48 hours apart.

2 coats brushed on 24 hours apart. 


\section{DISCUSSION OF RESULTS OF ABSORPTION TESTS UP TO ONE YEAR}

\section{ASPHALT EMULSIONS}

All the concrete specimens coated with asphalt emulsions show very little absorption for the first seven days, with the exception of No. 41 . This waterproofing is higher in clay content than the other waterproofings of this group. No. 5, the most efficient of this group, contains a high per cent of asbestos and was applied one-sixteenth inch thick. No. 42 is quite similar to No. 41 in chemical composition, but has been mixed with cement for the second coat and with sand and cement for the third coat. This probably accounts for the difference in efficiency between Nos. 41 and 42 . No. 41 is less absorbent than No. 42 for the first few hours, but breaks down quite rapidly after the first few periods. No. 6 contains a small amount of asbestos and was applied one-sixteenth inch thick. The other emulsions are applied in two coats and are not as efficient as the coatings containing asbestos. This group produces an appreciable reduction in absorption compared to the plain concrete.

\section{BITUMINOUS SOLUTIONS}

Nos. $16,18,21,23,29$, and 31 are asphalts cut in petroleum spirits. No. 23 contains a large percentage of asbestos and No. 29 contains a small amount of asbestos. The first three were applied in two coats and the last two were given one coat. No. 23 was applied one-eighth inch thick with a trowel. All of these show very little absorption for the first few days. Nos. 16 and 29 contain the highest percentage of asphalt of this group. No. 16 was quite low in absorption for the entire test. The difference in absorption between these two materials is probably due to the number of coats applied. Nos. 18 and 31 contain about the same amount of asphalt. Two coats of No. 18 resulted in lower absorption than one coat of No. 31. No. 21 contains a smaller amount of asphalt than No. 16 and a larger amount than No. 18 and has a corresponding efficiency. No. 23 was practically impervious to water throughout the test.

\section{FINELY GROUND IRON}

Nos. 17, 27, and 43 are finely ground iron mixed with sal ammoniac. They are less absorbent than the standard for the first few periods, but break down rapidly after a few days immersion in water. The difference in absorption is mainly due to the manner of application of the material. No. 17 was applied in five coats, No. 27 in two coats containing the material mixed with cement and sand. The coating was about one-eighth inch thick. No. 43 was applied in four coats, the third coat containing sand and cement and the fourth a slush or finish coat of sand and cement.

\section{CEMENT COATINGS}

Coatings Nos. 47,48 , and 49 are incorporated with a cement mix and then applied to the surface of the concrete. No. 47 is essentially a solution of calcium chloride. It is mixed with cement to a creamy consistency and applied in three coats. It is less absorbent for the 
first few hours, but breaks down quite rapidly. No. 48 is an acid solution of calcium chloride and aluminum chloride. No. 49 is a solution containing sodium silicate and glue. These last two materials are added to a mixture of Portland cement and sand to form a thick mortar and applied to the specimens one-fourth inch thick with a trowel. They are less absorbent than the uncoated concrete, particularly so at the early periods. This may possibly be due to the thick coating of mortar, regardless of the waterproofing added to it.

\section{TRANSPARENT COATINGS}

Sample No. 1 is a solution containing glycol. This is applied in two coats and is quite efficient for the first few periods but fails rapidly. Nos. 2,3 , and 4 are, respectively, butyl stearate, butyl oleate, and dibutyl phthalate. They were applied in three coats. With the exception of the phthalate these materials are quite efficient. No. 11 is boiled linseed oil and shows relatively excellent results. No. 46 contains a nondrying saponifiable oil and mineral oil. It is less absorbent for the first periods, but breaks down after 24 hours immersion in water. No. 25 contains a nondrying saponifiable oil, mineral oil, and paraffin. It is less absorbent for the first few hours, but breaks down after the first day. No. 37 is China wood oil cut in mineral spirits. This material showed the best results of all the transparent waterproofings tested.

Waterproofings Nos. $12,15,24,26,28,32,35,38,39,40,36$, and 19 are, in general, solutions of paraffin, waxes, etc., in mineral spirits or somewhat similar solvents. No. 50 is a solution of sodium silicate. These 13 waterproofings when applied to concrete are less absorbent than the uncoated concrete for the first few hours, but break down rapidly about the first day.

\section{PAINTS AND VARNISHES}

Samples Nos. 14,20 , and 44 contain varnish. No. 14 is a varnish mixed with asbestos to form a thick paste and was applied about onesixteenth inch thick with a trowel. This coating was quite efficient, but started to break down after six months. No. 20 is fairly efficient for the first four hours, but breaks down at 24 hours. No. 44 is quite efficient throughout the test. The paint coatings Nos. $22,30,33$, 34 , and 45 are all quite efficient for the first two or three months, but start to break down at the later periods.

\section{DISCUSSION OF RESULTS OF ABSORPTION TESTS SUB- SEQUENT TO ONE YEAR}

The absorption of the plain concrete was appreciably reduced in comparison with its original absorption at the corresponding time intervals of immersion. (See Table 4.). This was true of most of the coatings. They retained their relative position in per cent water absorbed at the different periods in comparison to the uncoated concrete with the following exceptions: The asphalt emulsion No. 41 was much less absorbent than originally. The bituminous solutions Nos. 29 and 31 showed about the same amounts of absorption as the standard. The finely ground iron coatings Nos. 17 and 43 were less absorbent than originally, but were more absorbent than the standard. 
The three cement coatings, Nos. 47,48 , and 49 , were appreciably less absorbent than the standard and much less absorbent compared to the corresponding periods of the original absorption results. The transparent coatings Nos. 46 and 25 were much less absorbent than they were originally. These two coatings contained a nondrying saponifiable oil. The paint coatings Nos. $30,33,34$, and 45 were more absorbent than the standard after the first few hours and also more absorbent than originally at the early periods.

TABLE 4.-Per cent absorption 3 by 6 inch concrete cylinders coated with surface waterproofing materials

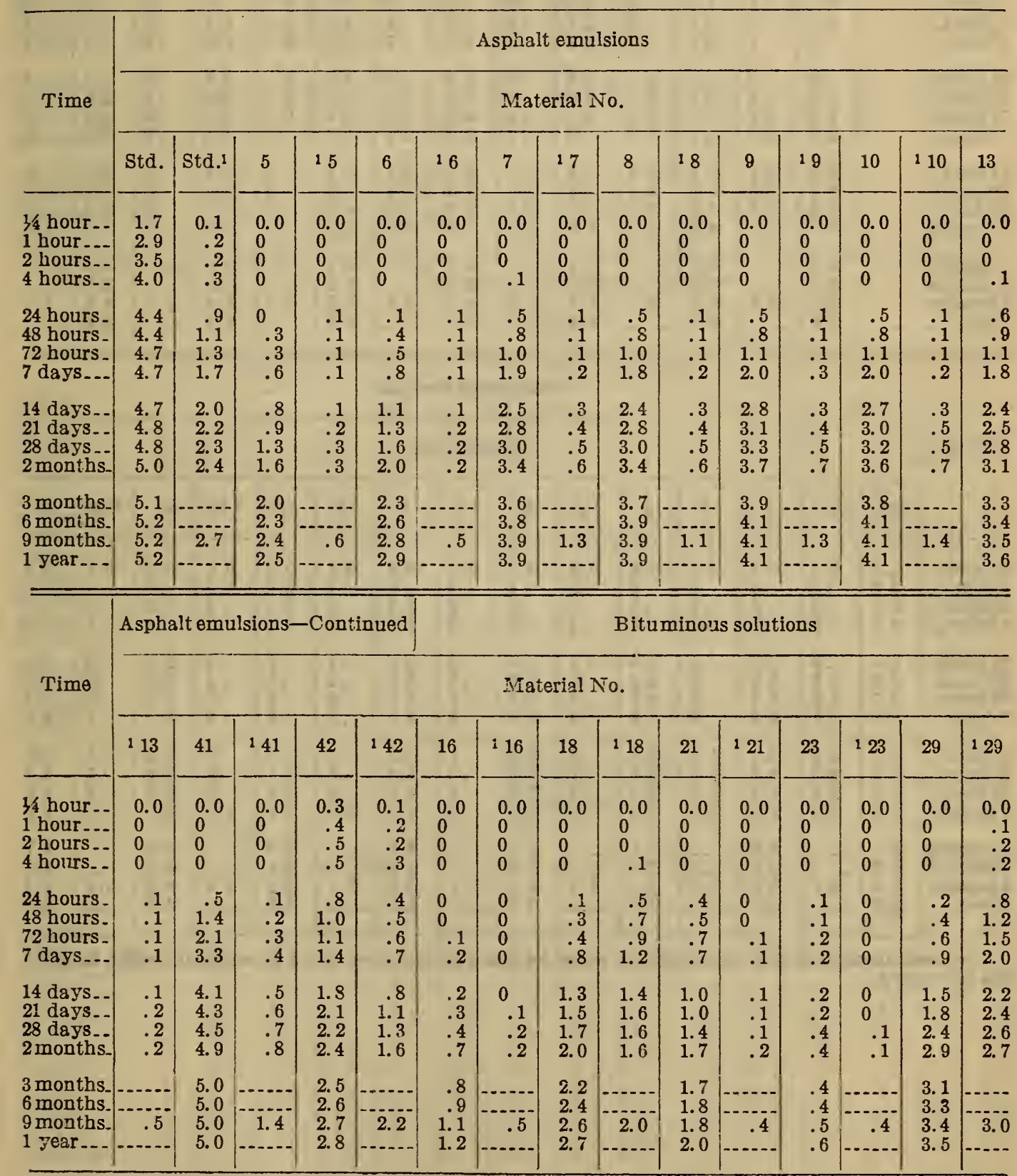

1 Per cent absorption after immersion in water for one year and then dried to constant weight in air of the laboratory. 
TABLE 4.-Per cent absorption 3 by 6 inch concrete cylinders coated with surface waterproofing materials-Continued

\begin{tabular}{|c|c|c|c|c|c|c|c|c|c|c|c|c|c|c|c|}
\hline \multirow{3}{*}{\multicolumn{2}{|c|}{ Time }} & \multicolumn{2}{|c|}{$\begin{array}{c}\text { Bituminous } \\
\text { solutions- } \\
\text { Continued }\end{array}$} & \multicolumn{6}{|c|}{ Finely ground iron } & \multicolumn{6}{|c|}{ Cement coatings } \\
\hline & & \multicolumn{14}{|c|}{ Material No. } \\
\hline & & 31 & 131 & 17 & 117 & 27 & ${ }^{1} 27$ & 43 & ${ }^{1} 43$ & 47 & 147 & 48 & 148 & 49 & 149 \\
\hline \multicolumn{2}{|l|}{$\begin{array}{l}1 / 4 \text { hour.... } \\
1 \text { hour.... } \\
2 \text { hours... } \\
4 \text { hours..- }\end{array}$} & $\begin{array}{l}0.0 \\
0 \\
0 \\
.1\end{array}$ & $\begin{array}{r}0.0 \\
.1 \\
.1 \\
.1\end{array}$ & $\begin{array}{l}0.7 \\
1.5 \\
2.1 \\
2.6\end{array}$ & $\begin{array}{r}0.4 \\
.8 \\
.9 \\
1.3\end{array}$ & $\begin{array}{l}1.4 \\
2.3 \\
2.8 \\
3.4\end{array}$ & $\begin{array}{r}0.2 \\
.2 \\
.4 \\
.4\end{array}$ & $\begin{array}{l}0.5 \\
.7 \\
1.1 \\
1.5\end{array}$ & $\begin{array}{r}0.2 \\
.4 \\
.5 \\
.7\end{array}$ & $\begin{array}{l}0.8 \\
2.0 \\
2.7 \\
3.5\end{array}$ & $\begin{array}{l}0.0 \\
0 \\
0 \\
0\end{array}$ & $\begin{array}{r}0.5 \\
.8 \\
1.1 \\
1.3\end{array}$ & $\begin{array}{l}0.1 \\
.2 \\
.2 \\
.2\end{array}$ & $\begin{array}{r}0.4 \\
.8 \\
1.1 \\
1.4\end{array}$ & $\begin{array}{l}0.1 \\
.2 \\
.2 \\
.4\end{array}$ \\
\hline \multicolumn{2}{|c|}{$\begin{array}{l}24 \text { hours } \\
48 \text { hours............. } \\
72 \text { hours } \\
7 \text { days }\end{array}$} & $\begin{array}{r}.3 \\
1.3 \\
1.8 \\
2.3\end{array}$ & $\begin{array}{r}.5 \\
.8 \\
1.2 \\
2.0\end{array}$ & $\begin{array}{l}3.8 \\
3.9 \\
3.9 \\
4.1\end{array}$ & $\begin{array}{l}2.1 \\
2.5 \\
2.7 \\
3.0\end{array}$ & $\begin{array}{l}4.5 \\
4.6 \\
4.7 \\
4.8\end{array}$ & $\begin{array}{r}.7 \\
.8 \\
.8 \\
1.1\end{array}$ & $\begin{array}{l}3.5 \\
3.9 \\
4.0 \\
4.2\end{array}$ & $\begin{array}{l}1.3 \\
1.6 \\
1.8 \\
2.1\end{array}$ & $\begin{array}{l}4.3 \\
4.4 \\
4.5 \\
4.5\end{array}$ & $\begin{array}{l}0 \\
0 \\
0 \\
.1\end{array}$ & $\begin{array}{l}2.4 \\
2.9 \\
3.0 \\
3.3\end{array}$ & $\begin{array}{l}.4 \\
.4 \\
.6 \\
.7\end{array}$ & $\begin{array}{l}2.3 \\
2.8 \\
3.0 \\
3.3\end{array}$ & $\begin{array}{l}.6 \\
.6 \\
.7 \\
.7\end{array}$ \\
\hline \multicolumn{2}{|c|}{$\begin{array}{l}14 \text { days...... } \\
21 \text { days } \\
28 \text { days } \\
2 \text { months }\end{array}$} & $\begin{array}{l}2.8 \\
2.9 \\
3.3 \\
3.5\end{array}$ & $\begin{array}{l}2.4 \\
2.6 \\
2.6 \\
2.7\end{array}$ & $\begin{array}{l}4.2 \\
4.2 \\
4.3 \\
4.6\end{array}$ & $\begin{array}{l}3.0 \\
3.1 \\
3.1 \\
3.1\end{array}$ & $\begin{array}{l}4.8 \\
4.8 \\
5.0 \\
5.2\end{array}$ & $\begin{array}{l}1.3 \\
1.4 \\
1.5 \\
1.5\end{array}$ & $\begin{array}{l}4.3 \\
4.5 \\
4.5 \\
4.6\end{array}$ & $\begin{array}{l}2.2 \\
2.5 \\
2.5 \\
2.6\end{array}$ & $\begin{array}{l}4.6 \\
4.6 \\
4.8 \\
5.0\end{array}$ & $\begin{array}{l}.1 \\
.3 \\
.4 \\
.4\end{array}$ & & $\begin{array}{l}.8 \\
.9 \\
.9 \\
.9\end{array}$ & $\begin{array}{l}3.5 \\
3.9 \\
3.9 \\
4.1\end{array}$ & $\begin{array}{r}.8 \\
.9 \\
.9 \\
1.0\end{array}$ \\
\hline \multirow{2}{*}{\multicolumn{2}{|c|}{$\begin{array}{l}3 \text { months.-.-.- } \\
6 \text { months.-- } \\
9 \text { months.-.-. } \\
1 \text { year }\end{array}$}} & $\begin{array}{l}3.5 \\
3.6 \\
3.7\end{array}$ & 2.9 & $\begin{array}{l}4.6 \\
4.8 \\
4.9\end{array}$ & & $\begin{array}{l}5.2 \\
5.3 \\
5.3\end{array}$ & 1.8 & $\begin{array}{l}4.6 \\
4.7 \\
4.8\end{array}$ & 2.7 & $\begin{array}{l}5.1 \\
5.2 \\
5.3\end{array}$ & 1.0 & $\begin{array}{l}4.0 \\
4.2 \\
4.4\end{array}$ & 1.2 & $\begin{array}{l}4.3 \\
4.5 \\
4.8\end{array}$ & 1.5 \\
\hline & & 3.8 & $\cdots$ & 4.9 & 0. & 5.4 & & 4.8 & & 5.3 & & 4.5 & & 4.8 & \\
\hline \multirow{3}{*}{ Time } & \multicolumn{15}{|c|}{ Transparent coatings } \\
\hline & \multicolumn{15}{|c|}{ Material No. } \\
\hline & Std. & Std. 1 & 1 & 11 & 2 & 12 & 3 & 13 & 4 & 14 & 11 & 111 & 46 & 146 & 25 \\
\hline $\begin{array}{l}1 / 4 \text { hour.. } \\
1 \text { hour.-- } \\
2 \text { hours.- } \\
4 \text { hours.- }\end{array}$ & $\begin{array}{l}\text { 1. } 7 \\
2.9 \\
3.5 \\
4.0\end{array}$ & $\begin{array}{l}0.1 \\
.2 \\
.2 \\
.3\end{array}$ & $\begin{array}{l}0.1 \\
.3 \\
.5 \\
.8\end{array}$ & $\begin{array}{l}0.0 \\
.1 \\
.1 \\
.1\end{array}$ & $\begin{array}{l}0.3 \\
.4 \\
.5 \\
.6\end{array}$ & $\begin{array}{r}0.2 \\
.2 \\
.2 \\
.2\end{array}$ & $\begin{array}{r}0.2 \\
.4 \\
.5 \\
.6\end{array}$ & $\begin{array}{r}0.1 \\
.2 \\
.2 \\
.2\end{array}$ & $\begin{array}{r}0.5 \\
.8 \\
1.2 \\
1.5\end{array}$ & $\begin{array}{l}0.1 \\
.1 \\
.1 \\
.1\end{array}$ & $\begin{array}{l}0.0 \\
0 \\
0 \\
0\end{array}$ & $\begin{array}{r}0.1 \\
.2 \\
.2 \\
.2\end{array}$ & $\begin{array}{r}0.3 \\
.7 \\
1.0 \\
1.4\end{array}$ & $\begin{array}{r}0.1 \\
.1 \\
.1 \\
.1\end{array}$ & $\begin{array}{r}0.3 \\
.5 \\
.7 \\
1.0\end{array}$ \\
\hline $\begin{array}{l}24 \text { hours - } \\
48 \text { hours - } \\
72 \text { hours - } \\
7 \text { days. - }\end{array}$ & $\begin{array}{l}4.4 \\
4.4 \\
4.7 \\
4.7\end{array}$ & $\begin{array}{l}.9 \\
1.1 \\
1.3 \\
1.7\end{array}$ & $\begin{array}{l}2.7 \\
3.5 \\
4.1 \\
4.4\end{array}$ & $\begin{array}{l}.2 \\
.3 \\
.5 \\
.8\end{array}$ & $\begin{array}{l}1.0 \\
1.2 \\
1.3 \\
1.8\end{array}$ & $\begin{array}{l}.5 \\
.5 \\
.5 \\
.5\end{array}$ & $\begin{array}{r}.9 \\
1.2 \\
1.5 \\
1.8\end{array}$ & $\begin{array}{l}.4 \\
.4 \\
.4 \\
.5\end{array}$ & $\begin{array}{l}3.3 \\
3.8 \\
4.1 \\
4.3\end{array}$ & $\begin{array}{l}.1 \\
.2 \\
.3 \\
.5\end{array}$ & $\begin{array}{l}.2 \\
.4 \\
.6 \\
.9\end{array}$ & $\begin{array}{l}.4 \\
.4 \\
.5 \\
.6\end{array}$ & $\begin{array}{l}2.9 \\
3.6 \\
3.9 \\
4.2\end{array}$ & $\begin{array}{l}.2 \\
.2 \\
.3 \\
.4\end{array}$ & $\begin{array}{l}2.3 \\
3.0 \\
3.4 \\
3.8\end{array}$ \\
\hline $\begin{array}{l}14 \text { days.-- } \\
21 \text { days.- } \\
28 \text { days.- } \\
2 \text { unonths }\end{array}$ & $\begin{array}{l}4.7 \\
4.8 \\
4.8 \\
5.0\end{array}$ & $\begin{array}{l}2.0 \\
2.2 \\
2.3 \\
2.4\end{array}$ & $\begin{array}{l}4.4 \\
4.4 \\
4.4 \\
4.6\end{array}$ & $\begin{array}{l}1.2 \\
1.4 \\
1.6 \\
1.8\end{array}$ & $\begin{array}{l}2.3 \\
2.5 \\
2.5 \\
2.9\end{array}$ & $\begin{array}{l}.6 \\
.7 \\
.8 \\
.8\end{array}$ & $\begin{array}{l}2.2 \\
2.3 \\
2.4 \\
2.9\end{array}$ & $\begin{array}{l}.7 \\
.7 \\
.8 \\
.8\end{array}$ & $\begin{array}{l}4.3 \\
4.4 \\
4.6 \\
4.7\end{array}$ & $\begin{array}{r}.6 \\
.8 \\
.9 \\
1.2\end{array}$ & $\begin{array}{l}1.0 \\
1.1 \\
1.2 \\
1.7\end{array}$ & $\begin{array}{r}.8 \\
.9 \\
.9 \\
1.0\end{array}$ & $\begin{array}{l}4.2 \\
4.5 \\
4.5 \\
4.7\end{array}$ & $\begin{array}{l}.5 \\
.7 \\
.7 \\
.9\end{array}$ & $\begin{array}{l}4.0 \\
4.2 \\
4.5 \\
4.6\end{array}$ \\
\hline $\begin{array}{l}3 \text { months } \\
6 \text { months } \\
9 \text { months } \\
1 \text { year... }\end{array}$ & $\begin{array}{l}5.1 \\
5.2 \\
5.2 \\
5.2\end{array}$ & 2.7 & $\begin{array}{l}4.7 \\
4.9 \\
5.0 \\
5.1\end{array}$ & 2.7 & $\begin{array}{l}3.1 \\
3.2 \\
3.3 \\
3.3\end{array}$ & 1.2 & $\begin{array}{l}3.2 \\
3.4 \\
3.4 \\
3.4\end{array}$ & 1.1 & $\begin{array}{l}4.8 \\
5.0 \\
5.0 \\
5.0\end{array}$ & 2.1 & $\begin{array}{l}2.0 \\
2.6 \\
3.3 \\
3.8\end{array}$ & 2.3 & $\begin{array}{l}4.8 \\
4.9 \\
4.9 \\
4.9\end{array}$ & 1.6 & $\begin{array}{l}4.7 \\
4.8 \\
4.8 \\
4.8\end{array}$ \\
\hline
\end{tabular}

1 Per cent absorption after immersion in water for one year and then dried to constant weight in air of the laboratory. 
TABLE 4.-Per cent absorption 3 by 6 inch concrete cylinders coated with surface waterproofing materials-Continued

\begin{tabular}{|c|c|c|c|c|c|c|c|c|c|c|c|c|c|c|c|}
\hline \multirow{3}{*}{ Time } & \multicolumn{15}{|c|}{ Transparent coatings-Continued } \\
\hline & \multicolumn{15}{|c|}{ Material No. } \\
\hline & 125 & 37 & 137 & 12 & ${ }^{1} 12$ & 15 & 115 & 24 & 124 & 26 & 126 & 28 & 128 & 32 & 132 \\
\hline $\begin{array}{l}1 / 4 \text { hour. } \\
1 \text { hour... } \\
2 \text { hours. } \\
4 \text { hours. }\end{array}$ & $\begin{array}{r}0.0 \\
.1 \\
.1 \\
.2\end{array}$ & $\begin{array}{r}0.0 \\
.1 \\
.1 \\
.2\end{array}$ & $\begin{array}{l}0.1 \\
.1 \\
.1 \\
.2\end{array}$ & $\begin{array}{l}0.5 \\
1.4 \\
2.1 \\
3.0\end{array}$ & $\begin{array}{r}0.1 \\
.1 \\
.1 \\
.2\end{array}$ & $\begin{array}{r}0.2 \\
.6 \\
.8 \\
1.5\end{array}$ & $\begin{array}{l}0.0 \\
.1 \\
.1 \\
.1\end{array}$ & $\begin{array}{l}1.2 \\
2.5 \\
3.2 \\
4.0\end{array}$ & $\begin{array}{r}0.1 \\
.2 \\
.3 \\
.5\end{array}$ & $\begin{array}{l}0.7 \\
1.7 \\
2.8 \\
3.5\end{array}$ & $\begin{array}{r}0.1 \\
.1 \\
.2 \\
.2\end{array}$ & $\begin{array}{r}0.3 \\
.8 \\
1.4 \\
2.3\end{array}$ & $\begin{array}{l}0.0 \\
0 \\
.1 \\
.1\end{array}$ & $\begin{array}{l}0.5 \\
1.3 \\
2.0 \\
2.9\end{array}$ & $\begin{array}{r}0.0 \\
.1 \\
.1 \\
.1\end{array}$ \\
\hline $\begin{array}{l}24 \text { hours } \\
48 \text { hours } \\
72 \text { hours - } \\
7 \text { days. }\end{array}$ & $\begin{array}{l}.3 \\
.3 \\
.4 \\
.5\end{array}$ & $\begin{array}{r}.5 \\
.8 \\
1.0 \\
1.5\end{array}$ & $\begin{array}{l}.2 \\
.3 \\
.3 \\
.5\end{array}$ & $\begin{array}{l}3.5 \\
3.9 \\
4.1 \\
4.1\end{array}$ & $\begin{array}{r}.6 \\
.9 \\
1.0 \\
1.5\end{array}$ & $\begin{array}{l}3.8 \\
4.4 \\
4.6 \\
4.6\end{array}$ & $\begin{array}{r}.3 \\
.6 \\
.7 \\
1.1\end{array}$ & $\begin{array}{l}4.4 \\
4.6 \\
4.6 \\
4.7\end{array}$ & $\begin{array}{l}1.2 \\
1.7 \\
1.9 \\
2.3\end{array}$ & $\begin{array}{l}4.5 \\
4.6 \\
4.8 \\
4.8\end{array}$ & $\begin{array}{l}.7 \\
1.0 \\
1.2 \\
1.7\end{array}$ & $\begin{array}{l}4.5 \\
4.7 \\
4.8 \\
4.8\end{array}$ & $\begin{array}{r}.4 \\
.6 \\
.8 \\
1.3\end{array}$ & $\begin{array}{l}4.1 \\
4.2 \\
4.2 \\
\text { 4. } 4\end{array}$ & $\begin{array}{r}.4 \\
.7 \\
.8 \\
1.2\end{array}$ \\
\hline $\begin{array}{l}14 \text { days - - } \\
21 \text { days.- } \\
28 \text { days - } \\
2 \text { months }\end{array}$ & $\begin{array}{l}.5 \\
.7 \\
.7 \\
.9\end{array}$ & $\begin{array}{l}1.7 \\
1.9 \\
1.9 \\
2.2\end{array}$ & $\begin{array}{l}.6 \\
.7 \\
.7 \\
.9\end{array}$ & $\begin{array}{l}4.3 \\
4.3 \\
4.3 \\
4.5\end{array}$ & $\begin{array}{l}1.8 \\
1.9 \\
2.1 \\
2.1\end{array}$ & $\begin{array}{l}4.8 \\
4.8 \\
4.9 \\
5.0\end{array}$ & $\begin{array}{l}1.6 \\
1.9 \\
2.1 \\
2.3\end{array}$ & $\begin{array}{l}4.8 \\
4.8 \\
4.8 \\
5.1\end{array}$ & $\begin{array}{l}2.4 \\
2.4 \\
2.5 \\
2.6\end{array}$ & $\begin{array}{l}4.9 \\
4.9 \\
4.9 \\
5.1\end{array}$ & $\begin{array}{l}2.1 \\
2.4 \\
2.6 \\
2.7\end{array}$ & $\begin{array}{l}4.8 \\
4.9 \\
4.9 \\
5.2\end{array}$ & $\begin{array}{l}1.9 \\
2.1 \\
2.3 \\
2.6\end{array}$ & $\begin{array}{l}4.4 \\
4.6 \\
4.6 \\
\text { 4. } 7\end{array}$ & $\begin{array}{l}1.6 \\
1.9 \\
1.9 \\
2.1\end{array}$ \\
\hline $\begin{array}{l}3 \text { months } \\
6 \text { months } \\
9 \text { months } \\
1 \text { year }\end{array}$ & 1.2 & $\begin{array}{l}2.3 \\
2.6 \\
2.7 \\
2.8\end{array}$ & 1.3 & $\begin{array}{l}4.6 \\
4.6 \\
4.6 \\
4.6\end{array}$ & 2.3 & $\begin{array}{l}5.1 \\
5.1 \\
5.2 \\
5.2\end{array}$ & 2.9 & $\begin{array}{l}\text { 5. } 2 \\
5.2 \\
5.2 \\
5.2\end{array}$ & 2.7 & $\begin{array}{l}5.1 \\
5.2 \\
5.2 \\
5.2\end{array}$ & 2.8 & $\begin{array}{l}5.2 \\
5.2 \\
5.2 \\
5.2\end{array}$ & 3.0 & $\begin{array}{l}4.7 \\
4.9 \\
4.9 \\
4.9\end{array}$ & 2.5 \\
\hline
\end{tabular}

\begin{tabular}{|c|c|c|c|c|c|c|c|c|c|c|c|c|c|c|}
\hline \multirow{3}{*}{ Time } & \multicolumn{14}{|c|}{ Transparent coatings-Continued } \\
\hline & \multicolumn{14}{|c|}{ Material No. } \\
\hline & 35 & 135 & 38 & 138 & 39 & 139 & 40 & 140 & 36 & 136 & 19 & 119 & 50 & ${ }^{1} 50$ \\
\hline $\begin{array}{l}1 / 4 \text { hour } \\
1 \text { hour...- } \\
2 \text { hours...- } \\
4 \text { hours.-. }\end{array}$ & $\begin{array}{r}0.3 \\
.5 \\
.9 \\
1.5\end{array}$ & $\begin{array}{l}0.0 \\
0 \\
0 \\
0\end{array}$ & $\begin{array}{r}0.2 \\
.4 \\
.7 \\
1.3\end{array}$ & $\begin{array}{r}0.0 \\
.1 \\
.2 \\
.2\end{array}$ & $\begin{array}{r}0.2 \\
.5 \\
.7 \\
1.2\end{array}$ & $\begin{array}{r}0.1 \\
.1 \\
.2 \\
.2\end{array}$ & $\begin{array}{r}0.2 \\
.6 \\
1.1 \\
1.5\end{array}$ & $\begin{array}{r}0.1 \\
.1 \\
.1 \\
.1\end{array}$ & $\begin{array}{r}0.3 \\
.6 \\
1.0 \\
1.6\end{array}$ & $\begin{array}{l}0.1 \\
.1 \\
.1 \\
.2\end{array}$ & $\begin{array}{l}0.4 \\
1.0 \\
1.8 \\
2.8\end{array}$ & $\begin{array}{l}0.0 \\
.1 \\
.1 \\
.2\end{array}$ & $\begin{array}{l}0.5 \\
1.5 \\
2.5 \\
3.3\end{array}$ & $\begin{array}{l}0.1 \\
.2 \\
.2 \\
.4\end{array}$ \\
\hline $\begin{array}{l}24 \text { hours } \\
48 \text { hours.-. } \\
72 \text { hours } \\
7 \text { days..- } \\
\end{array}$ & $\begin{array}{l}3.8 \\
4.6 \\
4.7 \\
4.9\end{array}$ & $\begin{array}{l}.2 \\
.4 \\
.5 \\
.9\end{array}$ & $\begin{array}{l}2.8 \\
3.7 \\
3.9 \\
4.5\end{array}$ & $\begin{array}{r}.6 \\
.9 \\
1.1 \\
1.7\end{array}$ & $\begin{array}{l}2.9 \\
3.7 \\
3.8 \\
4.2\end{array}$ & $\begin{array}{r}.6 \\
.8 \\
1.0 \\
1.5\end{array}$ & $\begin{array}{l}3.6 \\
4.3 \\
4.3 \\
4.5\end{array}$ & $\begin{array}{r}.5 \\
.7 \\
.8 \\
1.2\end{array}$ & $\begin{array}{l}3.7 \\
4.4 \\
4.4 \\
4.4\end{array}$ & $\begin{array}{r}.4 \\
.6 \\
.8 \\
1.2\end{array}$ & $\begin{array}{l}4.5 \\
4.5 \\
4.7 \\
4.7\end{array}$ & $\begin{array}{r}.6 \\
.8 \\
1.0 \\
1.5\end{array}$ & $\begin{array}{l}4.1 \\
4.2 \\
4.2 \\
4.3\end{array}$ & $\begin{array}{r}.9 \\
1.2 \\
1.4 \\
1.7\end{array}$ \\
\hline $\begin{array}{l}14 \text { days } \\
21 \text { days.- } \\
28 \text { days.- } \\
2 \text { months. }\end{array}$ & $\begin{array}{l}4.9 \\
4.9 \\
4.9 \\
5.2\end{array}$ & $\begin{array}{l}1.3 \\
1.6 \\
1.8 \\
2.3\end{array}$ & $\begin{array}{l}4.6 \\
4.8 \\
4.8 \\
5.0\end{array}$ & $\begin{array}{l}2.0 \\
2.1 \\
2.1 \\
2.3\end{array}$ & $\begin{array}{l}4.3 \\
4.5 \\
4.5 \\
4.9\end{array}$ & $\begin{array}{l}1.6 \\
2.1 \\
2.1 \\
2.3\end{array}$ & $\begin{array}{l}4.6 \\
4.7 \\
4.7 \\
5.0\end{array}$ & $\begin{array}{l}1.7 \\
1.9 \\
1.9 \\
2.1\end{array}$ & $\begin{array}{l}4.4 \\
4.6 \\
4.6 \\
4.8\end{array}$ & $\begin{array}{l}1.7 \\
2.0 \\
2.2 \\
2.5\end{array}$ & $\begin{array}{l}4.9 \\
5.0 \\
5.0 \\
5.1\end{array}$ & $\begin{array}{l}1.9 \\
2.3 \\
2.4 \\
2.6\end{array}$ & $\begin{array}{l}4.4 \\
4.8 \\
4.8 \\
4.9\end{array}$ & $\begin{array}{l}2.1 \\
2.2 \\
2.3 \\
2.3\end{array}$ \\
\hline $\begin{array}{l}3 \text { months.- } \\
6 \text { months.- } \\
9 \text { months.- } \\
1 \text { year.-.-. }\end{array}$ & $\begin{array}{l}5.2 \\
5.3 \\
5.3 \\
5.3\end{array}$ & 2.8 & $\begin{array}{l}5.1 \\
5.1 \\
5.2 \\
5.2\end{array}$ & 2.5 & $\begin{array}{l}5.0 \\
5.1 \\
5.1 \\
5.1\end{array}$ & 2.5 & $\begin{array}{l}5.1 \\
5.1 \\
5.3 \\
5.3\end{array}$ & 2.5 & $\begin{array}{l}4.9 \\
5.0 \\
5.0 \\
5.0\end{array}$ & 2.9 & $\begin{array}{l}5.2 \\
5.4 \\
5.4 \\
5.4\end{array}$ & 3.0 & $\begin{array}{l}5.0 \\
5.1 \\
5.1 \\
5.1\end{array}$ & 2.5 \\
\hline
\end{tabular}

\begin{tabular}{|c|c|c|c|c|c|c|c|c|c|c|c|c|c|c|}
\hline \multirow{3}{*}{ Time } & \multicolumn{14}{|c|}{ Paints and varnishes } \\
\hline & \multicolumn{14}{|c|}{ Material No. } \\
\hline & 14 & 114 & 20 & 120 & 22 & 122 & 30 & ${ }^{1} 30$ & $\begin{array}{c}33 \\
\text { and } \\
34\end{array}$ & $\begin{array}{c}133 \\
\text { and } \\
34\end{array}$ & 44 & 144 & 45 & 145 \\
\hline $\begin{array}{l}34 \text { hour } \\
1 \text { hour } \\
2 \text { hours. } \\
4 \text { hours }\end{array}$ & $\begin{array}{r}0.1 \\
.1 \\
.1 \\
.1\end{array}$ & $\begin{array}{l}0.1 \\
.2 \\
.2 \\
.3\end{array}$ & $\begin{array}{l}0.5 \\
1.0 \\
1.6 \\
2.4\end{array}$ & $\begin{array}{l}0.0 \\
.1 \\
.1 \\
.2\end{array}$ & $\begin{array}{l}0.0 \\
0 \\
0 \\
0\end{array}$ & $\begin{array}{r}0.1 \\
.2 \\
.2 \\
.2\end{array}$ & $\begin{array}{l}0.0 \\
0 \\
0 \\
0\end{array}$ & $\begin{array}{l}0.1 \\
.2 \\
.3 \\
.4\end{array}$ & $\begin{array}{l}0.0 \\
0 \\
0 \\
0\end{array}$ & $\begin{array}{l}0.1 \\
.2 \\
.5 \\
.7\end{array}$ & $\begin{array}{l}0.0 \\
0 \\
0 \\
.1\end{array}$ & $\begin{array}{r}0.0 \\
.1 \\
.1 \\
.2\end{array}$ & $\begin{array}{l}0.0 \\
0 \\
0 \\
0\end{array}$ & $\begin{array}{r}0.1 \\
.1 \\
.1 \\
.2\end{array}$ \\
\hline $\begin{array}{l}24 \text { hours } \\
48 \text { hours.-- } \\
72 \text { hours.- } \\
7 \text { days.-.- }\end{array}$ & $\begin{array}{l}.4 \\
.6 \\
.6 \\
.9\end{array}$ & $\begin{array}{r}.5 \\
.7 \\
.9 \\
1.1\end{array}$ & $\begin{array}{l}4.0 \\
4.2 \\
4.3 \\
4.3\end{array}$ & $\begin{array}{r}.5 \\
.6 \\
.8 \\
1.1\end{array}$ & $\begin{array}{l}.2 \\
.2 \\
.3 \\
.5\end{array}$ & $\begin{array}{l}.4 \\
.5 \\
.6 \\
.9\end{array}$ & $\begin{array}{l}.1 \\
.3 \\
.4 \\
.5\end{array}$ & $\begin{array}{l}1.0 \\
1.3 \\
1.5 \\
2.1\end{array}$ & $\begin{array}{l}.1 \\
.3 \\
.3 \\
.4\end{array}$ & $\begin{array}{l}1.6 \\
2.1 \\
2.3 \\
2.6\end{array}$ & $\begin{array}{l}.3 \\
.3 \\
.4 \\
.6\end{array}$ & $\begin{array}{l}.3 \\
.4 \\
.4 \\
.6\end{array}$ & $\begin{array}{l}0 \\
.1 \\
.3 \\
1.0\end{array}$ & $\begin{array}{l}.7 \\
1.7 \\
1.4 \\
2.2\end{array}$ \\
\hline $\begin{array}{l}14 \text { days.... } \\
21 \text { days... } \\
28 \text { days. } \\
2 \text { months. }\end{array}$ & $\begin{array}{l}1.2 \\
1.5 \\
1.6 \\
2.1\end{array}$ & $\begin{array}{l}1.5 \\
1.7 \\
1.7 \\
2.1\end{array}$ & $\begin{array}{l}4.4 \\
4.5 \\
4.5 \\
4.8\end{array}$ & $\begin{array}{l}1.4 \\
1.6 \\
1.8 \\
1.8\end{array}$ & $\begin{array}{l}.8 \\
1.1 \\
1.3 \\
2.1\end{array}$ & $\begin{array}{l}1.3 \\
1.5 \\
1.6 \\
1.9\end{array}$ & $\begin{array}{l}.8 \\
1.2 \\
1.4 \\
3.0\end{array}$ & $\begin{array}{l}2.4 \\
2.5 \\
2.6 \\
2.8\end{array}$ & $\begin{array}{r}.5 \\
.6 \\
.7 \\
1.2\end{array}$ & $\begin{array}{l}3.2 \\
3.3 \\
3.4 \\
3.5\end{array}$ & $\begin{array}{l}.9 \\
1.2 \\
1.4 \\
2.0\end{array}$ & $\begin{array}{r}.8 \\
.9 \\
.9 \\
1.1\end{array}$ & \begin{tabular}{l|}
2.1 \\
2.8 \\
3.3 \\
3.8
\end{tabular} & $\begin{array}{l}2.8 \\
3.0 \\
3.0 \\
3.1\end{array}$ \\
\hline $\begin{array}{l}3 \text { months.-. } \\
6 \text { months. } \\
9 \text { months. } \\
1 \text { year... }\end{array}$ & $\begin{array}{l}2.5 \\
3.4 \\
4.4 \\
5.2\end{array}$ & 2.9 & $\begin{array}{l}4.8 \\
4.9 \\
4.9 \\
4.9\end{array}$ & 2.3 & $\begin{array}{l}2.7 \\
3.6 \\
4.2 \\
4.4\end{array}$ & 2.6 & $\begin{array}{l}4.3 \\
4.8 \\
4.9 \\
4.9\end{array}$ & 3.0 & $\begin{array}{l}2.6 \\
4.6 \\
5.0 \\
5.1\end{array}$ & 3.7 & $\begin{array}{l}2.5 \\
3.1 \\
3.3 \\
3.5\end{array}$ & 1.9 & $\begin{array}{l}4.2 \\
4.3 \\
4.3 \\
4.4\end{array}$ & 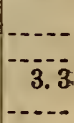 \\
\hline
\end{tabular}

1 Per cent absorption after immarsion in water for one year and then dried to constant weight in air of the laboratory. 


\section{SUMMARY (SURFACE)}

1. All of the surface coated concrete included in this investigation were less absorbent than the uncoated concrete for the first few periods (four hours) of immersion in water.

2. The most efficient coatings were some of the asphalt emulsions and bituminous solutions.

3. Linseed oil, China wood oil, and varnish were the most efficient transparent coatings.

4. Paints were quite effective for the first few months, but eventually broke down.

5. Drying out of the specimens after having been immersed in water for a year generally materially reduced the absorption of both the coated and uncoated specimens.

6 . If the amount by which the absorption of the uncoated specimen has been reduced by drying, is deducted from the absorption of the coated specimen after immersion for nine months, it will be noted that the resulting figure is very generally lower than the absorption at nine months of the coated specimen after drying. Therefore, the apparent reduction in the absorption of the coated specimen resulting from drying is due to the lower absorption of the concrete and not to any change in character of the coating.

\section{RESUME AND CONCLUSIONS}

1. This investigation, like that carried out previously by this bureau and reported in its Technologic Paper No. 3 shows the difficulty of demonstrating in the laboratory the value of waterproofings, both integral and for surfacing. It is not a difficult matter to make a concrete that is impermeable to water under heads as great as 20 lbs./in. ${ }^{2}$ Such pressures exceed those encountered in by far the greater majority of concrete structures. Hence, since concrete can be so made without the use of waterpoofings, they would seem to be needless.

2. But in the placing of even very excellent concrete, it happens that it may become segregated partially into its constituents in certain places. When such places are too lean in mortar or cement paste, they will permit of the passage of water and consequently waterproofings are a matter of consideration. Doubtlessly some of the integral agents do give an unctuousness and ease of placing which tends to prevent segregation. Also others are of a nature such as to render concrete water repellent when sprinkled or subject to the precipitation of rain. Further, some might react with the cement so as to reduce voids in segregated portions through an unusual :swelling of the hydrated cement. Hence, it does seem that these materials should be subject of study.

3. The lean concrete used was purposely adopted as simulating the lean segregated portion of concrete through which leakage generally occurs. If the integral waterproofings could reduce its permeability, they should be considered as of some merit. Some have been found to be of this nature; others seem to be valueless.

4. The lapse of time since the bureau's first study of such materials has not been prolific in producing new waterproofing agents. The names of the products are generally different, but a study of their 
composition shows that they are, with few exceptions, of the same nature as previously. The ammonical copper solution of cellulose seems to be the only distinctly different new material.

5. The autogenous sealing up of the slightly leaking concrete seems to be quite an effective means of obtaining water tightness. This condition seems to result just as readily when no waterproofing agent is present as when one is.

6 . The marked increase in permeability on drying the concrete specimens also characterizes field concrete. Although not carried out in this study, repeated wetting and drying generally gradually reduces leakage, however, only provided the leakage originally is not too great. In such a case, solution of the concrete results in increased permeability.

7. Attention needs hardly to be called to the fact that integral compounds are valueless if the concrete cracks through settlement, shrinkage, etc.

8. The simpler materials, such as the stearates, which can be bought in open competitive markets without paying for fanciful trade names are as effective as any.

9. Calcium chloride, although it can be readily purchased as such, is still a marked favorite, at least with sellers, under striking names and further camouflaged through the use of dyes.

10. The water emulsions of asphalt are relatively new, and generally their efficiency is well demonstrated by this study. It would seem, however, that manufacturers of these products should give them further study particularly as to the mineral extenders which they are incorporating in them. Although the data are meager, it appears that asbestos is a better mineral extender than clay. The cut asphalt applied as paints also gave good results. It should be remembered, however, that a year is a short period in the required life of a coating in actual service.

11. The coatings composed largely of inorganic pastes, such as iron oxide, cement, etc., gave poor results according to the test procedure used. Such coatings still have enough finer pores to permit of sufficient capillarity to give a high absorption. It is possible that under a higher head they might appear more promising. The paint coatings act also rather poorly apparently for the same reason.

12. Some of the transparent coatings gave good results. Striking among these are such readily obtainable materials as linseed and China wood (tung) oil.

13. In the case of leakage due to cracks following settlement or shrinkage, the use of coatings tending to seal over autogeneously should be considered in preference to the others not having this property. Such consideraion would bring the bituminous coatings to the fore.

\section{ACKNOWLEDGMENTS}

The author wishes to express his appreciation of the aid and cooperation of the following: W. Dean Kimmel in the preparation and testing of the specimens used in the investigation; to W. $\mathrm{H}$. Cannon for the chemical analyses of the materials used; and to G. L. Kalousek for the compilation and preparation of data.

Washington, October 23, 1931. 